\title{
Combustion Emissions Modeling and Testing of Neat Biodiesel Fuels
}

\author{
H-P. Liu ${ }^{1}$, S. Strank ${ }^{1}$, M. Werst ${ }^{1}$, R. Hebner ${ }^{1}$, and J. Osara ${ }^{2}$ \\ ${ }^{1}$ Center for Electromechanics, University of Texas at Austin, Austin, TX 78712 \\ ${ }^{2}$ Department of Mechanical Engineering, University of Texas at Austin, Austin, TX 78712
}

\begin{abstract}
This paper presents emissions modeling and testing of a four-stroke single cylinder diesel engine using pure soybean, cottonseed, and algae biodiesel fuels. A system level engine simulation tool developed by Gamma Technologies, GT-Power, has been used to perform predictive engine combustion simulations using direct-injection jet modeling technique.

Various physical and thermodynamic properties of the biodiesel fuels in both liquid and vapor states are required by the GT-Power combustion simulations. However, many of these fuel properties either do not exist or are not available in published literatures. The properties of the individual fatty esters, that comprise a biofuel, determine the overall fuel properties of the biofuel. In this study, fatty acid profiles of the soybean, cottonseed, and algae methylester biodiesel fuels have been identified and used for fuel property calculations. The predicted thermo-physical properties of biodiesels were then provided as fuel property inputs in the biodiesel combustion simulations.

Using the calculated biodiesel fuel properties and an assumed fuel injector sac pressure profile, engine emissions of the conventional diesel and biodiesel fuels have been predicted from combustion simulations to investigate emission impacts of the biodiesel fuels. Soybean biodiesel engine emissions, which include $\mathrm{NO}_{\mathrm{x}}, \mathrm{HC}, \mathrm{CO}$ and $\mathrm{CO}_{2}$, measured at various engine speeds and loads in actual combustion emissions tests performed in this study were also compared to those predicted by the combustion simulations.
\end{abstract}

\section{Key Words - biodiesel fuels, combustion, emissions modeling, emissions testing}

\section{1-INTRODUCTION}

Due to the rapid decline of crude oil reserves, research and development have been carried out to derive new fuels extracted from renewable feedstock. Among the different fuel sources, vegetable oils have been considered as alternative to substitute the traditional diesel fuels. Extensive testing has shown that diesel engines can be operated satisfactorily on "raw" vegetable oils. Unlike hydrocarbon-based fuels, the sulphur content of the vegetable oils is close to zero; hence, the use of vegetable oil essentially eliminates the environmental damage caused by sulphuric acid. However, the high viscosities of vegetable oils tend to alter the injector spray pattern inside the combustion engine. In addition, residues and carbon deposits could cause problems with fuel injectors, piston rings, and oil stability.

The undesirable vegetable oil characteristics can be substantially changed by reacting its triglyceride molecules with lighter alcohol molecules. By reacting the neat oils with methanol or ethanol, esters are formed which have much improved fuel characteristics. Biodiesel fuel, fatty acid methyl ester, derived 
from triglycerides by transesterification with methanol has received most of the attention due to its renewability, improved exhaust emissions, and biodegradability. Compared to conventional diesel fuel, the higher cetane number of biodiesel results in shorter ignition delay and longer combustion duration and hence, low particulate emissions [1]. Biodiesel can be used in its pure form (B100), which may require certain engine modifications to avoid maintenance and performance problems, or blended with petroleum diesel. Common blends include B2 (2\% biodiesel), B5, and B20. In general, the main benefits of the biodiesel use are reductions in petroleum consumption and greenhouse gas emissions.

Among various biodiesel fuels, soybean biodiesel has been widely used as a substitute of fossil diesel due to its availability on the market. However, there are numerous other feedstock fuels under consideration. Effects of the viscosity of cottonseed oil methyl ester (COME), which is decreased by means of preheating, on engine performance and exhaust emissions of a diesel engine were experimentally studied [2], and the test results revealed that preheating COME to $90^{\circ} \mathrm{C}$ led to favorable effects on brake thermal efficiency and $\mathrm{CO}$ emissions. Microalgae, as biomass, are also a potential renewable energy source. The microalgae are grown in photo-bioreactors or in open ponds, and the algae oil is converted to algae biodiesel through a transesterification process. A number of methods have been reported to convert the microalgae to liquid fuel and gas, either using biochemical or thermochemical processes [3].

These new biodiesel fuels have physical and chemical properties that are quite different from those of the conventional petroleum fuels. The viscosities of methyl esters are similar to, but in most cases are somewhat higher than that of the diesel fuel. This could potentially have an impact on the quantity of fuel injected by the diesel engine fuel injection systems. As compared to conventional No. 2 diesel fuel, the neat biodiesel fuels have lower heating value, higher viscosity, higher fuel density, and contain approximately $10 \%$ oxygen.

This study consisted of conducting predictive combustion simulations, using a direct-injection jet modeling technique with an assumed fuel injector sac pressure profile, to predict and evaluate exhaust emissions for pure soybean, cottonseed, algae biodiesel and conventional diesel fuels. Since the neat soybean biodiesel is readily available from the market, engine emissions, which include $\mathrm{NO}_{\mathrm{x}}, \mathrm{HC}, \mathrm{CO}$ and $\mathrm{CO}_{2}$, of this particular biodiesel were physically measured during this study in combustion emissions tests of a four-stroke single cylinder diesel engine at various engine speed-load combinations and the measured soybean biodiesel emissions were compared to those predicted by the combustion simulations.

\section{2-COMBUSTION EMISSIONS MODELING}

GT-Power software, developed by Gamma Technologies as a system level engine simulation tool, has been used to study combustion characteristics and emissions of diesel, vegetable oils, and biodiesel fuels [4-7]. In this study, predictive GT-Power combustion simulations using Direct-Injection Jet (DIJet) modeling technique have been performed to predict burn rates and combustion emissions of three different neat biodiesel fuels, which include soybean, cottonseed, and algae biodiesel fuels. The analytical background of the GT-Power DIJet modeling can be found in [4, 8].

The fuel injection pressure profile, pressure versus crank angle, required by the GT-Power DIJet modeling is a pressure profile in the injector sac which is a small volume inside the injector between the plunger and the spray nozzles. The fuel injector sac pressure is difficult to measure due to limited 
accessibility, very high pressure, and the high frequency response required. The testing technique developed in the laboratory for the fuel injector sac pressure measurement has been described in a paper [4] written by the authors of this research. A pair of fast response absolute pressure transducers was installed on the fuel injection line of the test engine to measure the fuel injection pressures at the fuel pump end and nozzle holder end, and the sac pressure was then calculated using industry standard calculations [4].

For diesel engine combustion simulations, many physical and thermodynamic properties of the diesel and biodiesel fuels are required in the GT-Power DIJet models. The required liquid and vapor fuel properties are listed as follows:

- Liquid state: heat of vaporization, density, enthalpy of liquid, temperature-dependent kinematic viscosities, temperature-dependent thermal conductivities

- Vapor state: lower heating value, critical temperature, critical pressure, enthalpy of vapor, temperature-dependent kinematic viscosities, temperature-dependent thermal conductivities, carbon atoms per molecule, hydrogen atoms per molecule, oxygen atoms per molecule, nitrogen atoms per molecule

Extensive search of the above-described physical and thermodynamic properties for soybean, cottonseed and algae biofuels has been conducted in this study. However, it was found that many of these biofuel property data do not exist. Estimation of various biofuel properties required by the GT-Power combustion simulations, several that are temperature dependent, has been a significant effort made in this research.

\section{3-CALCULATION OF BIODIESEL FUEL PROPERTIES}

The properties of various individual fatty esters that comprise a biofuel determine the overall fuel properties of the biofuel. Structural features of fatty ester molecules that influence fuel properties are chain length, degree of unsaturation, and branching of the chain. Important biofuel properties influenced by fatty acid profiles are cetane number and ultimately exhaust emissions, heat of combustion, cold flow, viscosity, and lubricity [9]. The fatty acid profiles of soybean, cottonseed, and algae biofuels have been identified after extensive literature searches and are included in tables 1 to 5. Because the fatty acid profiles of the cottonseed oil and cottonseed biodiesel are similar, the cottonseed oil fatty acid profiles shown in table 2 were assumed to be those of the cottonseed biodiesels and used for cottonseed biodiesel fuel property calculations in this study.

Table 1. Fatty acid profiles of soybean biofuels (by mass fraction of each component ester)

\begin{tabular}{|c|c|c|c|c|c|c|}
\hline Fatty Acid & $\begin{array}{c}\text { Carbon } \\
\text { Number }\end{array}$ & $\begin{array}{c}\text { Carbon } \\
\text { Atoms }\end{array}$ & $\begin{array}{c}\text { Double } \\
\text { Bonds }\end{array}$ & $\begin{array}{c}\text { Soybean } \\
\text { Methylester }^{10}\end{array}$ & $\begin{array}{c}\text { Soybean } \\
\text { Methylester }^{11}\end{array}$ & $\begin{array}{c}\text { Soybean } \\
\text { Methylester }^{12}\end{array}$ \\
\hline Myristic & C14:0 & 14 & 0 & & 0.2 & \\
\hline Palmitic & C16:0 & 16 & 0 & 10.81 & 10.2 & 16.3 \\
\hline Palmitoleic & C16:1 & 16 & 1 & 0.11 & & \\
\hline Stearic & C18:0 & 18 & 0 & 4.54 & 4.6 & 6 \\
\hline Oleic & C18:1 & 18 & 1 & 24.96 & 22.2 & 24.3 \\
\hline
\end{tabular}




\begin{tabular}{|c|c|c|c|c|c|c|} 
Linoleic & C18:2 & 18 & 2 & 50.66 & 54.6 & 53.4 \\
\hline Linolenic & C18:3 & 18 & 3 & 7.27 & 8.2 & \\
\hline Arachidic & C20:0 & 20 & 0 & 0.37 & & \\
\hline Gadoleic & C20:1 & 20 & 1 & 0.32 & & \\
\hline Behenic & C22:0 & 22 & 0 & 0.42 & & \\
\hline Lignoceric & C24:0 & 24 & 0 & 0.12 & & \\
\hline Sum & & & & 99.58 & 100 & 100 \\
\hline
\end{tabular}

Table 2. Fatty acid profiles of cottonseed biofuels (by mass fraction of each component ester)

\begin{tabular}{|c|c|c|c|c|c|c|}
\hline Fatty Acid & $\begin{array}{c}\text { Carbon } \\
\text { Number }\end{array}$ & $\begin{array}{c}\text { Carbon } \\
\text { Atoms }\end{array}$ & $\begin{array}{c}\text { Double } \\
\text { Bonds }\end{array}$ & $\begin{array}{c}\text { Cottonseed } \\
\text { Oil }^{11}\end{array}$ & $\begin{array}{c}\text { Cottonseed } \\
\text { Oil }^{13}\end{array}$ & $\begin{array}{c}\text { Cottonseed } \\
\text { Oil }^{14}\end{array}$ \\
\hline Myristic & C14:0 & 14 & 0 & 0.8 & & 0.7 \\
\hline Palmitic & C16:0 & 16 & 0 & 22.9 & 28.33 & 21.79 \\
\hline Palmitoleic & C16:1 & 16 & 1 & & & 0.56 \\
\hline Stearic & C18:0 & 18 & 0 & 3.1 & 0.89 & 2.48 \\
\hline Oleic & $\mathrm{C} 18: 1$ & 18 & 1 & 18.5 & 13.27 & 12.02 \\
\hline Linoleic & $\mathrm{C} 18: 2$ & 18 & 2 & 54.2 & 57.51 & 61.62 \\
\hline Linolenic & $\mathrm{C} 18: 3$ & 18 & 3 & 0.5 & & \\
\hline Arachidic & $\mathrm{C} 20: 0$ & 20 & 0 & & & \\
\hline Other & & & & 100 & 100 & 0.36 \\
\hline Sum & & & & & & 100 \\
\hline
\end{tabular}

Table 3. Fatty acid methyl esters of triglycerides of nitrogen starved green algal neochloris oleoabundans [15]

\begin{tabular}{|c|c|c|}
\hline Fatty Acid Identity & Mol. Wt. & Area (\%) \\
\hline $14: 0$ & 242 & 1.6 \\
\hline $14: 1$ & 240 & 0.4 \\
\hline $15: 0$ & 256 & 0.4 \\
\hline iso-15:0 & 256 & 1.0 \\
\hline $16: 0$ & 270 & 15.0 \\
\hline $16: 1$ & 268 & 3.5 \\
\hline $16: 2$ & 266 & 2.5 \\
\hline $17: 0$ & 284 & 3.3 \\
\hline iso-17:0 & 284 & 8.4 \\
\hline $17: 1$ & 282 & 1.0 \\
\hline $18: 0$ & 298 & 11.0 \\
\hline $18: 1$ & 296 & 36.0 \\
\hline $18: 2$ & 294 & 7.4 \\
\hline $19: 0$ & 312 & 0.3 \\
\hline
\end{tabular}




\begin{tabular}{|c|c|c|}
\hline iso-19:0 & 312 & 0.5 \\
\hline $19: 1$ & 310 & 0.1 \\
\hline $20: 0$ & 326 & 2.1 \\
\hline $20: 1$ & 324 & 2.5 \\
\hline Sum & & 97.0 \\
\hline
\end{tabular}

Table 4. Most abundant species in macroalgae biodiesel identified by using supercritical $\mathrm{CO}_{2}[16]$ (These should sum to $100 \%$ and the difference is due to cumulative rounding and measurement errors.)

\begin{tabular}{|c|c|}
\hline Fatty Acid Methyl Esters & $\%$ \\
\hline Methyl Miristate (14:0) & 9.8 \\
\hline Methyl Palmitate (16:0) & 32 \\
\hline Methyl Palmitoleate (16:1) & 3.3 \\
\hline Methyl Stearate (18:0) & 1.5 \\
\hline Methyl Oleate (18:1) & 14.2 \\
\hline Methyl Linoleate (18:2) & 21.4 \\
\hline Methyl Eicosanoate (20:0) & 0.3 \\
\hline Methyl Arachidonate (20:4) & 1.6 \\
\hline Methyl Eicosapentaenoate (20:5) & 2.6 \\
\hline Methyl Tetracosanoate (24:0) & 0.6 \\
\hline Others* & 18.3 \\
\hline Sum & 105.6 \\
\hline
\end{tabular}

*Other fatty acids identified: 15:0, 17:0, 14:1, 16:1, 16:2, 16:3, 18:3, 18:4, 20:2, 22:5

Table 5. Fatty acid methyl esters in microalga biodiesel [17]

\begin{tabular}{|c|c|c|c|}
\hline Fatty Acid Methyl Esters & $\begin{array}{c}\text { Molecular } \\
\text { Formula }\end{array}$ & $\begin{array}{c}\text { Relative } \\
\text { Molecular } \\
\text { Mass }\end{array}$ & $\begin{array}{c}\text { Relative } \\
\text { Content } \\
\text { (\%) }\end{array}$ \\
\hline Methyl Tetradecanoate (14:0) & $\mathrm{C}_{15} \mathrm{H}_{30} \mathrm{O}_{2}$ & 242 & 1.31 \\
\hline Hexadecanoic Acid Methyl Ester (16:0) & $\mathrm{C}_{17} \mathrm{H}_{34} \mathrm{O}_{2}$ & 270 & 12.94 \\
\hline Heptadecanoic Acid Methyl Ester (17:0) & $\mathrm{C}_{18} \mathrm{H}_{36} \mathrm{O}_{2}$ & 284 & 0.89 \\
\hline Octadecanoic Acid Methyl Ester (18:0) & $\mathrm{C}_{19} \mathrm{H}_{38} \mathrm{O}_{2}$ & 298 & 2.76 \\
\hline 9-Octadecenoic Acid Methyl Ester (18:1) & $\mathrm{C}_{19} \mathrm{H}_{36} \mathrm{O}_{2}$ & 296 & 60.84 \\
\hline 9,12-Octadecadienoic Acid Methyl Ester (18:2) & $\mathrm{C}_{19} \mathrm{H}_{34} \mathrm{O}_{2}$ & 294 & 17.28 \\
\hline 10-Nonadecenoic Acid Methyl Ester (19:1) & $\mathrm{C}_{20} \mathrm{H}_{38} \mathrm{O}_{2}$ & 310 & 0.36 \\
\hline Eicosanoic Acid Nethyl Ester (20:0) & $\mathrm{C}_{21} \mathrm{H}_{42} \mathrm{O}_{2}$ & 326 & 0.35 \\
\hline 11-Eicosenioc Acid Methyl Ester (20:1) & $\mathrm{C}_{21} \mathrm{H}_{40} \mathrm{O}_{2}$ & 324 & 0.42 \\
\hline Sum & & & 97.15 \\
\hline
\end{tabular}


The chemical content in an algae cell can be a function of species, growth conditions, harvesting conditions, and processing conditions and these are not necessarily independent variables. Consequently the information in tables 3, 4 and 5 is interpreted as being typical rather than definitive. Furthermore, different studies under differing conditions would be expected to yield different results. Insufficient data are available at this time to bound the degree of expected variability.

Yuan $[10,18]$ developed a computer program "BDProp" to calculate the physical and thermodynamic properties of pure biodiesels (B100) based on their fatty acid compositions by using various property estimation and computational methods. The BDProp-predicted biodiesel fuel properties have been compared to measured or published fuel property data and found to be sufficiently accurate for use as fuel definitions for pure biodiesel combustion modeling. Permission has been given by Yuan to use the BDProp program to calculate the biodiesel properties that are of interest in this study.

BDProp was primarily developed to generate pure biodiesel fuel properties required for engine combustion simulations using KIVA-3V code, which is a program used for three-dimensional fluid dynamics modeling for chemically reacting flows. The biodiesel properties calculated by the BDProp program include critical properties, density, vapor pressure, enthalpy, heat of vaporization, surface tension, viscosity, and molecular chemical structure. Most of the fuel properties calculated by the BDProp are for the "liquid" state only.

The predicted critical properties of selected biodiesels are included in table 6, in which the critical properties of No. 2 diesel were obtained from the GT-Power fuel library. The predicted normal boiling temperatures, molecular structures, and molecular weights are included in table 7. Soybean, cottonseed, and algae methyl esters are abbreviated as SME, CME, and AME, respectively. The numerical values appended to the abbrieviations of biodiesel identify associated references listed in this paper.

Table 6. Critical properties of soybean, cottonseed, algae biodiesels (calculated by BDProp) and No. 2 diesel (obtained from GT-Power fuel library)

\begin{tabular}{|c|c|c|c|c|c|c|c|c|c|c|}
\hline & SME-10 & SME-11 & SME-12 & CME-11 & CME-13 & CME-14 & AME-15 & AME-16 & AME-17 & $\begin{array}{c}\text { No. 2 } \\
\text { Diesel }\end{array}$ \\
\hline $\begin{array}{c}\text { Critical } \\
\text { Temperature } \\
\text { (K) }\end{array}$ & 783.83 & 784.67 & 781.24 & 779.72 & 779.62 & 781.51 & 768.59 & 764.36 & 773.07 & 569.4 \\
\hline $\begin{array}{c}\text { Critical } \\
\text { Pressure } \\
\text { (bar) }\end{array}$ & 12.02 & 12.07 & 12.04 & 12.15 & 12.20 & 12.18 & 11.87 & 12.44 & 11.84 & 24.6 \\
\hline $\begin{array}{c}\text { Critical } \\
\text { Volume } \\
\left(\mathrm{mm}^{3} / \mathrm{mil}\right)\end{array}$ & 1084.16 & 1081.52 & 1079.81 & 1070.61 & 1066.52 & 1070.14 & 1078.78 & 1033.83 & 1086.18 & \\
\hline
\end{tabular}

Table 7. Normal boiling temperatures, molecular structures, and molecular weights of soybean, cottonseed, algae biodiesels (calculated by BDProp)

\begin{tabular}{|c|c|c|c|}
\hline & SME-10 & SME-11 & SME-12 \\
\hline $\begin{array}{c}\text { Normal Boiling } \\
\text { Temperature }\end{array}$ & 627.074 & 627.396 & 624.1 \\
\hline
\end{tabular}




\begin{tabular}{|c|c|c|c|} 
& & & \\
\hline Molecular Structure & $\mathrm{C}_{18.7946} \mathrm{H}_{34.6256} \mathrm{O}_{2}$ & $\mathrm{C}_{18.77} \mathrm{H}_{34.4441} \mathrm{O}_{2}$ & $\mathrm{C}_{18.6493} \mathrm{H}_{34.7109} \mathrm{O}_{2}$ \\
\hline $\begin{array}{c}\text { Molecular Weight } \\
(\mathrm{g} / \mathrm{mol})\end{array}$ & 292.161 & 291.684 & 290.503 \\
\hline
\end{tabular}

\begin{tabular}{|c|c|c|c|}
\hline & CME-11 & CME-13 & CME-14 \\
\hline $\begin{array}{c}\text { Normal Boiling } \\
\text { Temperature } \\
(\mathrm{K})\end{array}$ & 621.045 & 620.436 & 622.7 \\
\hline $\begin{array}{c}\text { Molecular Structure } \\
\text { Molecular Weight } \\
(\mathrm{g} / \mathrm{mol})\end{array}$ & $\mathrm{C}_{18.4732} \mathrm{H}_{34.432} \mathrm{O}_{2}$ & $\mathrm{C}_{18.3976} \mathrm{H}_{34.2917} \mathrm{O}_{2}$ & $\mathrm{C}_{18.4934} \mathrm{H}_{34.3116} \mathrm{O}_{2}$ \\
\hline & 288.11 & 287.063 & 288.232 \\
\hline
\end{tabular}

\begin{tabular}{|c|c|c|c|}
\hline & AME-15 & AME-16 & AME-17 \\
\hline $\begin{array}{c}\text { Normal Boiling } \\
\text { Temperature } \\
(\mathrm{K})\end{array}$ & 627.787 & 606.011 & 619.68 \\
\hline $\begin{array}{c}\text { Molecular Structure } \\
\mathrm{C}_{18.3922} \mathrm{H}_{35.5701} \mathrm{O}_{2}\end{array}$ & $\mathrm{C}_{17.6236} \mathrm{H}_{33.873} \mathrm{O}_{2}$ & $\mathrm{C}_{18.6514} \mathrm{H}_{35.351} \mathrm{O}_{2}$ \\
\hline $\begin{array}{c}\text { Molecular Weight } \\
(\mathrm{g} / \mathrm{mol})\end{array}$ & 288.277 & 277.356 & 291.168 \\
\hline
\end{tabular}

The fuel thermal conductivity, which dictates thermal conduction in the fuel spray, required by GT-Power modeling cannot be calculated by BDProp. To estimate temperature-dependent thermal conductivities of biodiesels at their liquid states, two methods, one developed by Latini, et al. and the other by Sastri, were identified [21]. The Latini method introduces significant error unless $50<$ molecular weight $<250$. As shown in table 7, the molecular weights of the biodiesels of interest are all greater than 250 . Therefore, the Sastri method has been chosen to calculate the thermal conductivities of the liquid biodiesels.

Sastri recommends

$$
\lambda_{\mathrm{L}}=\lambda_{\mathrm{b}} \mathrm{a}^{\mathrm{m}}
$$

where

$$
\mathrm{m}=1-\left(\frac{1-\mathrm{T}_{\mathrm{r}}}{1-\mathrm{T}_{\mathrm{br}}}\right)^{\mathrm{n}}
$$

$\lambda_{\mathrm{L}}$ is the thermal conductivity $(\mathrm{W} / \mathrm{m}-\mathrm{K})$ of the liquid, $\lambda_{\mathrm{b}}$ is the thermal conductivity at the normal boiling point and is determined by group contributions, $T_{r}$ is the reduced temperature, $T_{b r}$ is the reduced 
temperature at the boiling point. For alcohols and phenols, $\mathrm{a}=0.856$ and $\mathrm{n}=1.23$. For other compounds, $\mathrm{a}=0.16$ and $\mathrm{n}=0.2$. Sastri reported an average deviation of $8 \%$ for 186 points that were tested.

For each biodiesel fuel group, three different fatty acid compositions, shown in tables 1 to 7 , have been used for property calculations. Examining the calculated properties of each biodiesel group, it was found that the magnitude of difference for each property value among the three biodiesels selected for the soybean, cottonseed, and algae groups are relatively small. Therefore, only one biodiesel out of each biodiesel fuel group was analyzed in the GT-Power combustion simulation. The selected representative biodiesels are SME-11 for the soybean biodiesel group, CME-11 for the cottonseed biodiesel group, and AME-17 for the algae biodiesel group. The predicted temperature-dependent densities, heat of vaporization, dynamic viscosities, and thermal conductivities of those selected biodiesel fuel representatives at the liquid state are plotted in figures 1 to 4 . The above-mentioned fuel properties for the No. 2 diesel are also available in published literatures, and they have been included in figures 1 to 4 for comparisons with those of the biodiesels.

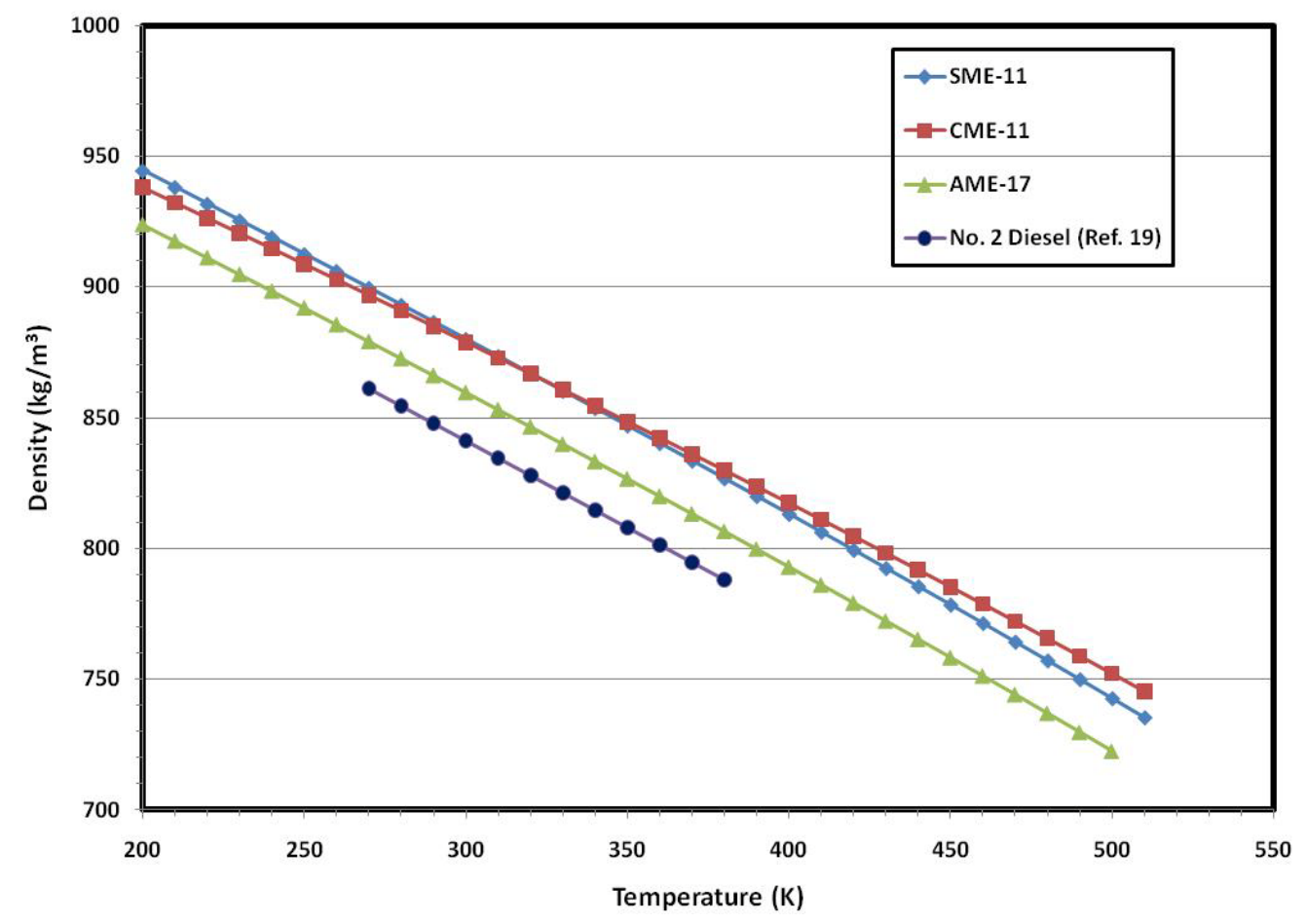

Figure 1. Densities of selected methyl ester biodiesel and No. 2 diesel liquids 


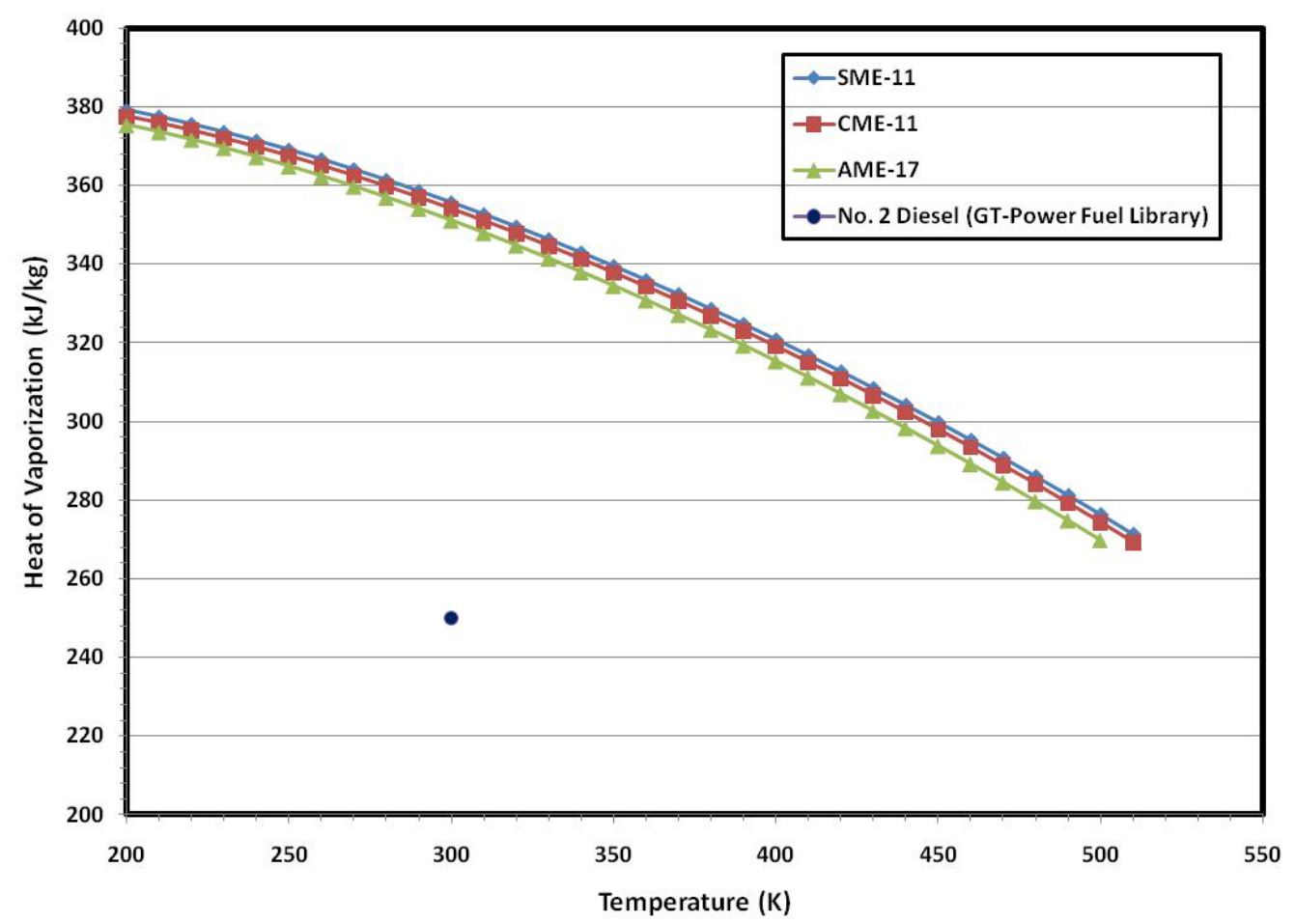

Figure 2. Heat of Vaporization of selected methyl ester biodiesel and No. 2 diesel liquids

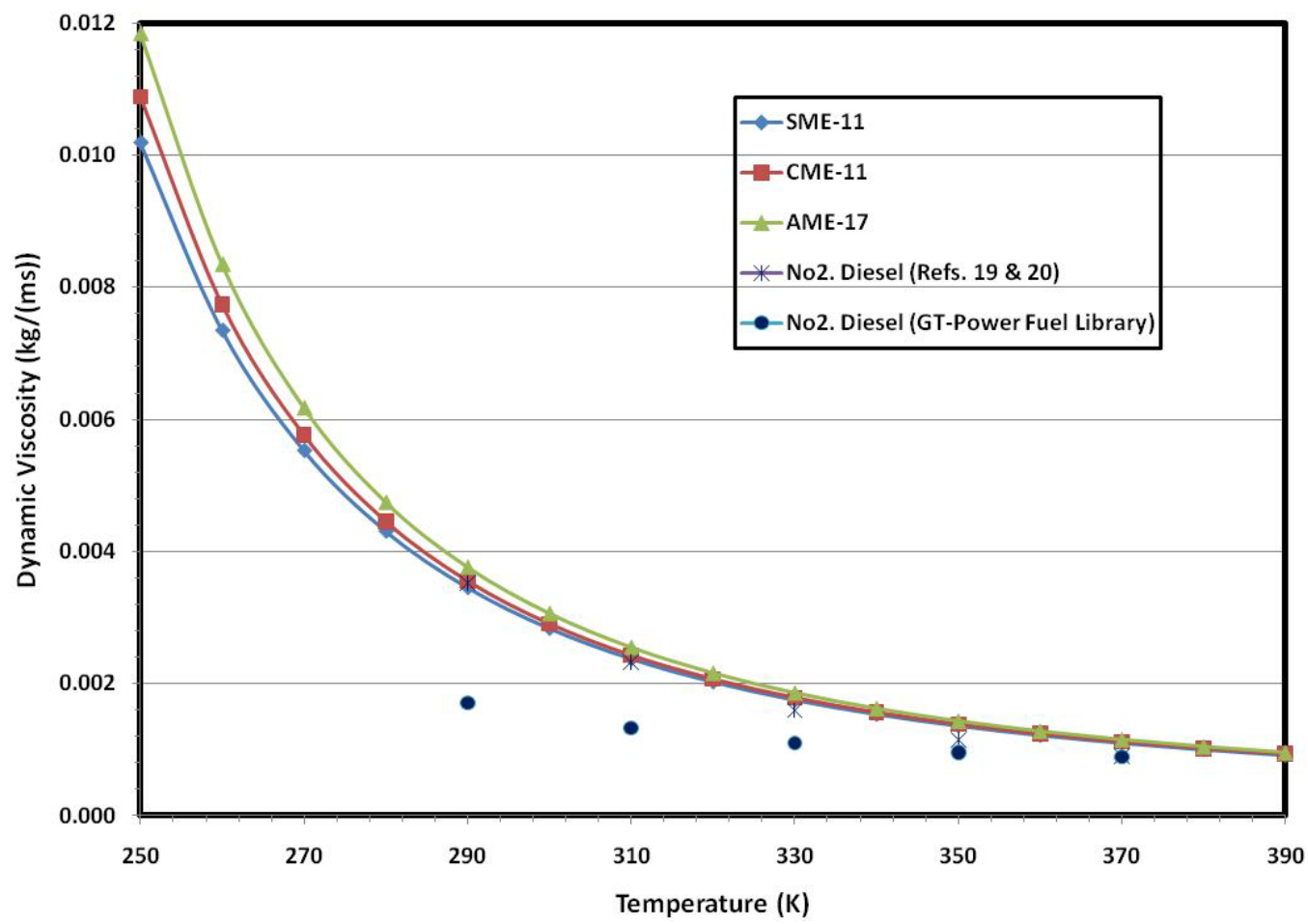

Figure 3. Dynamic viscosities of selected methyl ester biodiesel and No. 2 diesel liquids 


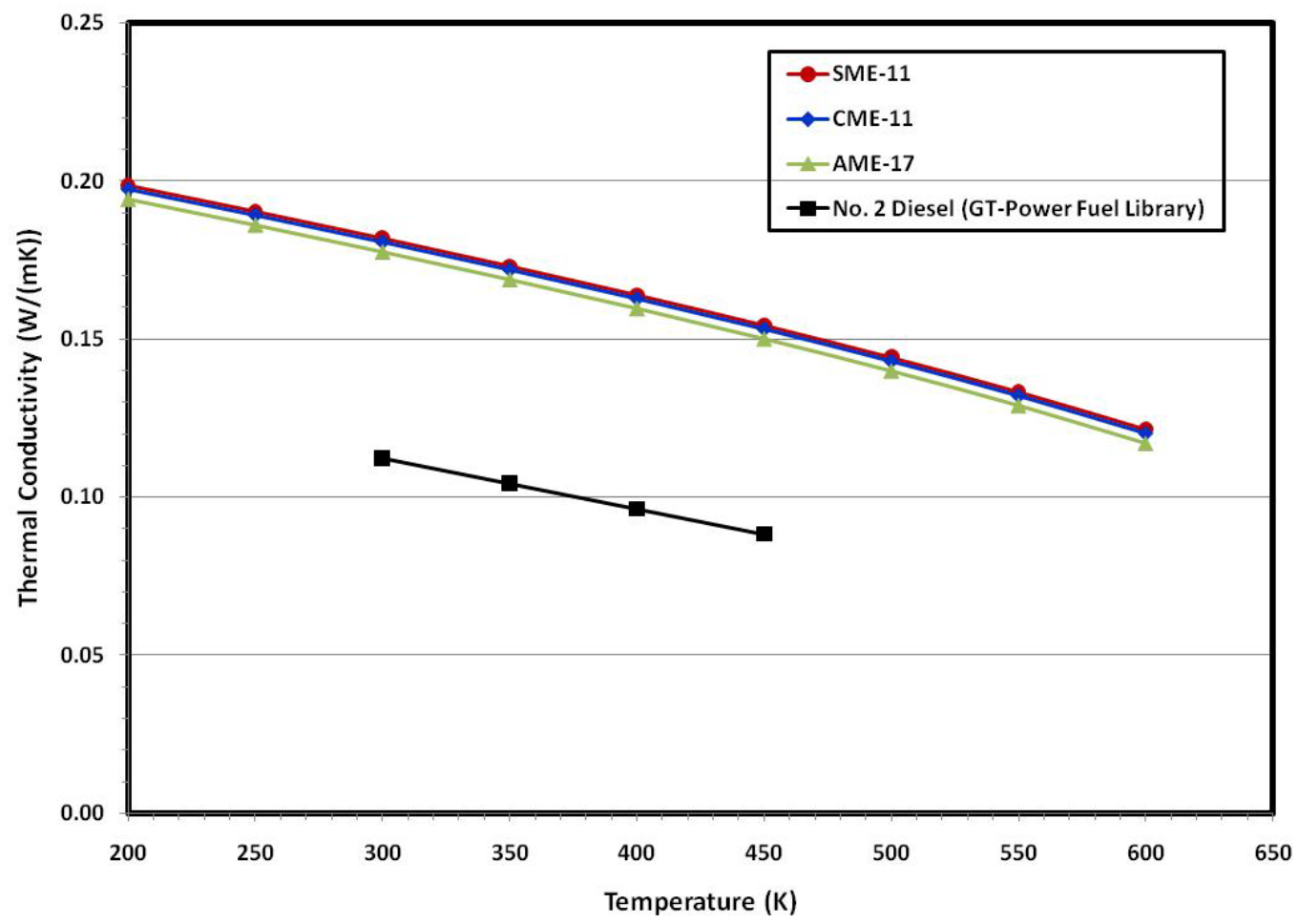

Figure 4. Thermal conductivities of selected methyl ester biodiesel and No. 2 diesel liquids

GT-Power combustion simulations require fuel properties in both liquid and vapor states. The fuel properties calculated by BDProp code are for "liquid" state only. This study has conducted a literature search to find techniques to estimate the following biodiesel fuel properties which cannot be predicted by BDProp, but are required for the GT-Power simulation inputs.

- Temperature-dependent vapor viscosities of biodiesels

- Temperature-dependent vapor thermal conductivities of biodiesels

- Enthalpy constants of biodiesels for both liquid and vapor states

It is logical to assume the vapor fuel properties are largely determined by the fatty acid compositions of the biodiesels. The fatty acid profiles of those biodiesels that are interested in this study are summarized in table 8. The temperature-dependent viscosity and thermal conductivity data for the vapor of methyl oleate (C18:1) were found in reference [22]. Since biodiesel fuels contain significant amount of methyl oleate (shown in table 8), the vapor property data of methyl oleate can be approximated to be those of the soybean, cottonseed, and algae biodiesel vapors. The temperature dependent dynamic viscosities and thermal conductivities of the methyl oleate vapor (or biodiesel vapors) are shown in figures 5 and 6 . 
Table 8. Fatty acid profiles of soybean, cottonseed, and algae biodiesel fuels

\begin{tabular}{|c|c|c|c|c|c|}
\hline $\begin{array}{c}\text { Fatty Acid } \\
\text { (Trivial Name) }\end{array}$ & $\begin{array}{c}\text { Fatty Acid } \\
\text { (Systematic Name) }\end{array}$ & Structure & Soybean & Cottonseed & Algae \\
\hline Lauric & Dodecanoic & C12:0 & & & \\
\hline Myristic & Tetradecanoic & C14:0 & 0.2 & 0.8 & 1.31 \\
\hline Palmitic & Hexadecanoic & C16:0 & 10.2 & 22.9 & 12.94 \\
\hline Palmitoleic & 9-Hexadecenoic & C16:1 & & & \\
\hline Margaric & Heptadecanoic & C17:0 & & & 0.89 \\
\hline Stearic & Octadecanoic & C18:0 & 4.6 & 3.1 & 2.76 \\
\hline Oleic & 9-Octadecenoic & C18:1 & 22.2 & 18.5 & 60.84 \\
\hline Linoleic & $\begin{array}{c}\text { 9,12- } \\
\text { Octadecadienoic }\end{array}$ & C18:2 & 54.6 & 54.2 & 17.28 \\
\hline \multirow[t]{2}{*}{ Linolenic } & $\begin{array}{c}9,12,15- \\
\text { Octadecatrienoic }\end{array}$ & C18:3 & 8.2 & 0.5 & \\
\hline & 10-Nonadecenoic & C19:1 & & & 0.36 \\
\hline Arachidic & Eicosanoic & C20:0 & & & 0.35 \\
\hline Gadoleic & 9-Eicosenoic & C20:1 & & & 0.42 \\
\hline Behenic & Docosanoic & $\mathrm{C} 22: 0$ & & & \\
\hline Lignoceric & Tetracosanoic & $\mathrm{C} 24: 0$ & & & \\
\hline Sum & & & 100 & 100 & 97.15 \\
\hline
\end{tabular}

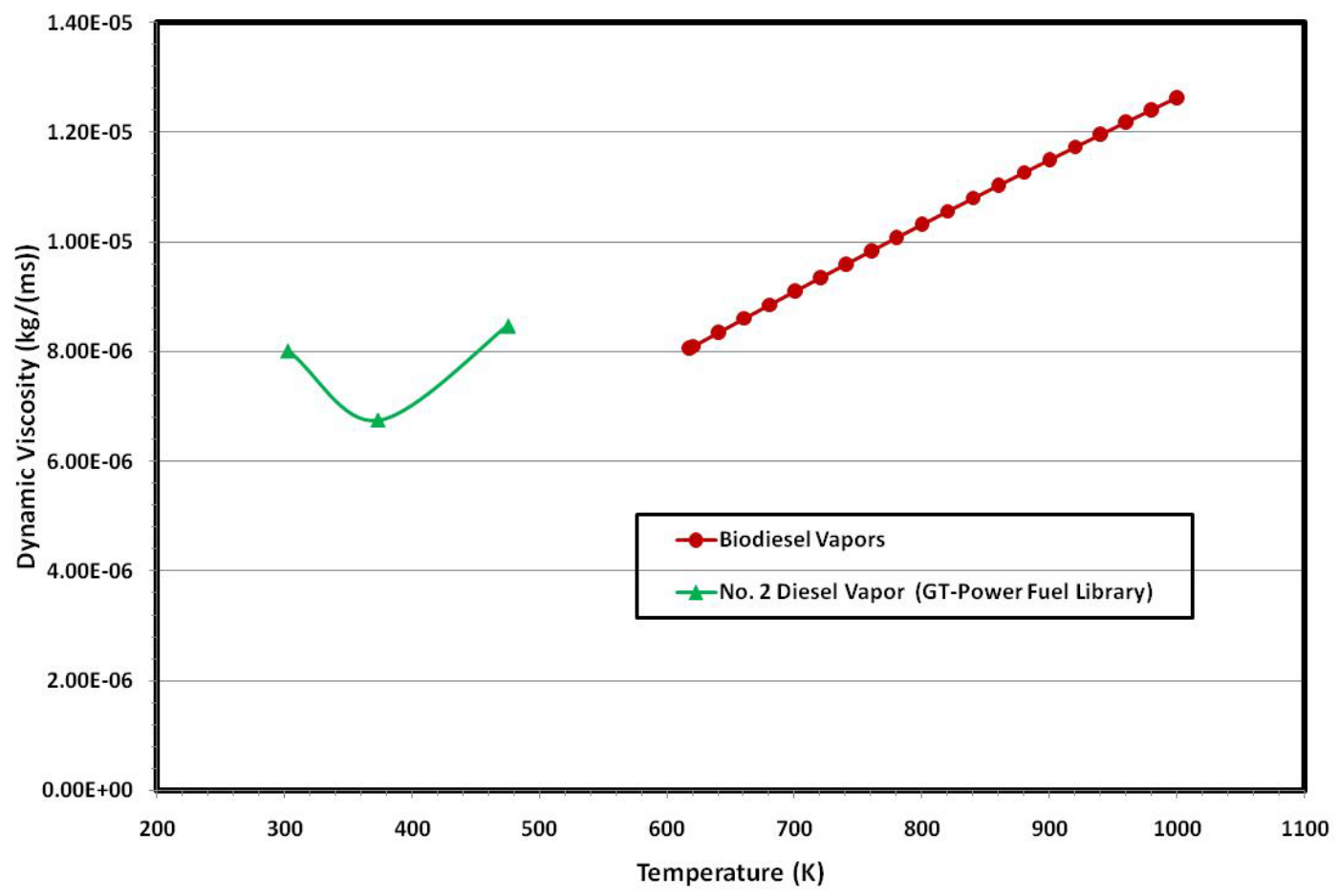

Figure 5. Temperature-dependent No. 2 diesel and biodiesel vapor dynamic viscosities 


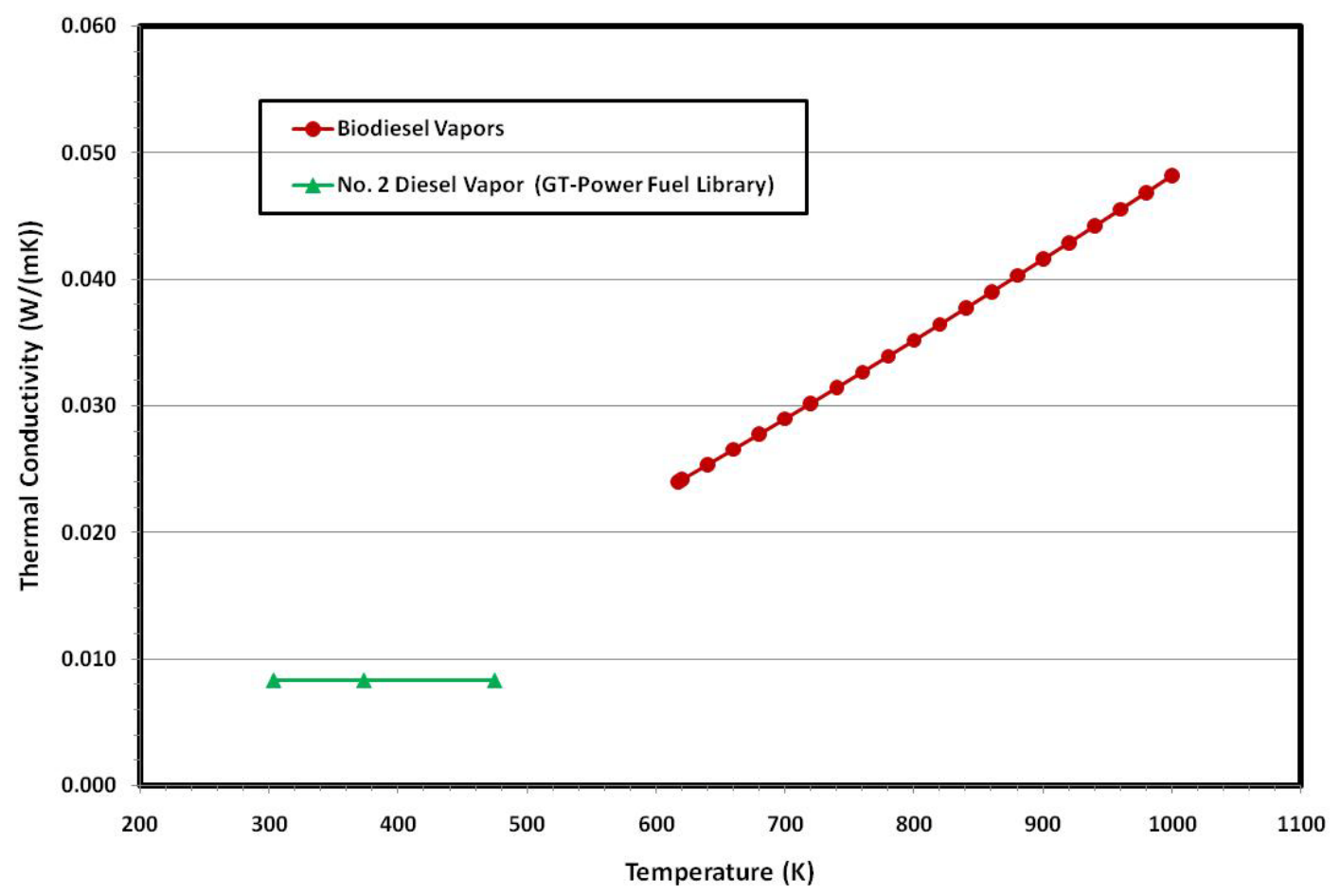

Figure 6. Temperature-dependent No. 2 diesel and biodiesel vapor thermal conductivities

Computational methods have been identified to estimate soybean, cottonseed, and algae biodiesel enthalpy constants, these parameters are required by the GT-Power combustion simulation but cannot be calculated by the BDProp computer program. The enthalpy of a biodiesel fuel is dependent on the fuel's fatty acid compositions. Since the biodiesel fuels are mainly made of C14:0, C16:0, C18:0, C18:1, and C18:2 methyl esters, for simplicity, the biodiesel composition percentages shown in table 8 were somewhat adjusted and redistributed to these five common fatty acid methyl esters. Table 9 shows the redistributed biodiesel compositions, which were used in the calculations of biodiesel enthalpy constants.

Table 9. Adjusted fatty acid profiles of soybean, cottonseed, and algae biodiesel fuels

\begin{tabular}{|c|c|c|c|c|}
\hline $\begin{array}{c}\text { Fatty Acid } \\
\text { (Trivial Name) }\end{array}$ & Structure & Soybean & Cottonseed & Algae \\
\hline Myristic & C14:0 & 0.2 & 0.8 & 1.3 \\
\hline Palmitic & C16:0 & 10.2 & 22.9 & 13.3 \\
\hline Stearic & C18:0 & 4.6 & 3.1 & 3.8 \\
\hline Oleic & C18:1 & 22.2 & 18.5 & 62.6 \\
\hline Linoleic & C18:2 & 62.8 & 54.7 & 18.9 \\
\hline Sum & & 100 & 100 & 100 \\
\hline
\end{tabular}


The enthalpy constants of a diesel or biodiesel fuel required by the GT-Power are defined by:

- For liquid:

$$
\mathrm{h}-\mathrm{h}_{\mathrm{ref}}=\mathrm{a}_{1}\left(\mathrm{~T}-\mathrm{T}_{\mathrm{ref}}\right)+\mathrm{a}_{2}\left(\mathrm{~T}-\mathrm{T}_{\mathrm{ref}}\right)^{2}+\mathrm{a}_{3}\left(\mathrm{~T}-\mathrm{T}_{\mathrm{ref}}\right)^{3}
$$

- For vapor:

$$
h-h_{\text {ref }}=a_{1}\left(T-T_{\text {ref }}\right)+a_{2}\left(T-T_{\text {ref }}\right)^{2}+a_{3}\left(T-T_{\text {ref }}\right)^{3}+a_{4}\left(T-T_{\text {ref }}\right)^{4}+a_{5}\left(T-T_{\text {ref }}\right)^{5}
$$

Rowlinson-Bondi method [21] can be used to estimate the liquid heat capacity of nonpolar or slightly polar compounds. This method is represented by the following equation:

$$
\frac{\mathrm{C}_{\mathrm{pL}}-\mathrm{C}_{\mathrm{p}}^{0}}{\mathrm{R}}=1.45+0.45\left(1-\mathrm{T}_{\mathrm{r}}\right)^{-1}+0.25 \omega\left[17.11+25.2\left(1-\mathrm{T}_{\mathrm{r}}\right)^{1 / 3} \mathrm{~T}_{\mathrm{r}}^{-1}+1.742\left(1-\mathrm{T}_{\mathrm{r}}\right)^{-1}\right]
$$

Where

$\mathrm{C}_{\mathrm{pL}}=$ heat capacity of liquid at constant pressure $(\mathrm{J} / \mathrm{mol}-\mathrm{K})$

$\mathrm{C}_{\mathrm{p}}{ }^{0}=$ heat capacity of liquid at a reference state $(\mathrm{J} / \mathrm{mol}-\mathrm{K})$

$\mathrm{R}=$ Gas constant $(8.314 \mathrm{~J} / \mathrm{mol}-\mathrm{K})$

$\mathrm{T}_{\mathrm{r}}=$ reduced temperature

$\omega=$ Pitzer acentric factor

The Pitzer acentric factor can be calculated using the following correlations:

$$
\begin{aligned}
& \omega=\frac{\alpha}{\beta} \\
& \alpha=-\ln \left(\mathrm{P}_{\mathrm{c}}\right)-5.97214+6.09648 \theta^{-1}+1.28862 \ln (\theta)-0.169347 \theta^{6} \\
& \beta=15.2518-15.6875 \theta^{-1}-13.4721 \ln (\theta)+0.43577 \theta^{6} \\
& \theta=\frac{\mathrm{T}_{\mathrm{b}}}{\mathrm{T}_{\mathrm{c}}}
\end{aligned}
$$

Where

$\mathrm{P}_{\mathrm{c}}=$ critical pressure (atmospheres)

$\mathrm{T}_{\mathrm{b}}=$ normal boiling point $(\mathrm{K})$

$\mathrm{T}_{\mathrm{c}}=$ critical temperature $(\mathrm{K})$

The published normal boiling points [10] and BDProp-calculated critical pressures and critical temperatures of the common pure methyl esters found in biodiesel fuels are included in table 10. 
Table 10. Normal boiling points and critical-point properties of common pure methyl esters found in biodiesel fuels

\begin{tabular}{|c|c|c|c|}
\hline Compositions & $\begin{array}{c}\text { Normal } \\
\text { Boiling Point } \\
(\mathrm{K})\end{array}$ & $\begin{array}{c}\text { Critical } \\
\text { Pressure } \\
\text { (bar) }\end{array}$ & $\begin{array}{c}\text { Critical } \\
\text { Temperature } \\
(\mathrm{K})\end{array}$ \\
\hline $\mathrm{C} 14: 0$ & 568 & 14.0246 & 730.433 \\
\hline $\mathrm{C} 16: 0$ & 611 & 12.5785 & 754.031 \\
\hline $\mathrm{C} 18: 0$ & 625 & 11.3499 & 774.134 \\
\hline $\mathrm{C} 18: 1$ & 622 & 11.5675 & 772.283 \\
\hline $\mathrm{C} 18: 2$ & 639 & 12.1736 & 795.269 \\
\hline
\end{tabular}

Chueh-Swanson method [21] has proposed to use group contribution approach to estimate the liquid heat capacity at a room temperature of $293 \mathrm{~K}$. The group contribution method assumes that various groups in a molecule contribute a definite value to the total molar heat capacity that is independent of other groups present. Group contributions related to the biodiesel fuels are shown in table 11. The chemical structures of common biodiesel fatty acids [23] are shown in table 12.

Table 11. Group contributions for molar liquid heat capacity at $293 \mathrm{~K}$ for Chueh-Swanson method

\begin{tabular}{|c|c|}
\hline Group & Value $(\mathrm{J} / \mathrm{mol}-\mathrm{K})$ \\
\hline$-\mathrm{CH}_{3}$ & 36.8 \\
\hline$-\mathrm{CH}_{2-}$ & 30.4 \\
\hline$=\mathrm{CH}-$ & 21.3 \\
\hline$-\mathrm{COO}-$ & 60.7 \\
\hline
\end{tabular}

Table 12. Chemical structures of common biodiesel fatty acids

\begin{tabular}{|c|c|c|}
\hline Fatty Acid & $\begin{array}{c}\text { Molecular } \\
\text { Formula }\end{array}$ & Chemical Structure \\
\hline Myristic (14:0) & $\mathrm{C}_{14} \mathrm{H}_{28} \mathrm{O}_{2}$ & $\mathrm{CH}_{3}\left(\mathrm{CH}_{2}\right)_{12} \mathrm{COOH}$ \\
\hline Palmitic (16:0) & $\mathrm{C}_{16} \mathrm{H}_{32} \mathrm{O}_{2}$ & $\mathrm{CH}_{3}\left(\mathrm{CH}_{2}\right)_{14} \mathrm{COOH}$ \\
\hline Stearic (18:0) & $\mathrm{C}_{18} \mathrm{H}_{36} \mathrm{O}_{2}$ & $\mathrm{CH}_{3}\left(\mathrm{CH}_{2}\right)_{16} \mathrm{COOH}$ \\
\hline Oleic (18:1) & $\mathrm{C}_{18} \mathrm{H}_{34} \mathrm{O}_{2}$ & $\mathrm{CH}_{3}\left(\mathrm{CH}_{2}\right)_{7} \mathrm{CH}=\mathrm{CH}\left(\mathrm{CH}_{2}\right)_{7} \mathrm{COOH}$ \\
\hline Linoleic (18:2) & $\mathrm{C}_{18} \mathrm{H}_{32} \mathrm{O}_{2}$ & $\mathrm{CH}_{3}\left(\mathrm{CH}_{2}\right)_{4} \mathrm{CH}=\mathrm{CHCH}_{2} \mathrm{CH}=\mathrm{CH}\left(\mathrm{CH}_{2}\right)_{7} \mathrm{COOH}$ \\
\hline
\end{tabular}

The following procedures were used to calculate the liquid heat capacity of a biodiesel at a given temperature: 
- Individually calculate the heat capacity of each fatty acid methyl ester composition and convert it into a mass basis

- Compute the overall heat capacity of a biodiesel using the mass composition of the biodiesel for weight averaging

To calculate the enthalpy, the biodiesel heat capacity can be integrated with respect to the temperature as follows:

$$
\mathrm{h}-\mathrm{h}_{\mathrm{ref}}=\int_{\text {Tref }}^{\mathrm{T}} \mathrm{C}_{\mathrm{p}} \mathrm{dT}
$$

Where

$$
\begin{aligned}
& \mathrm{h}=\text { enthalpy }(\mathrm{J} / \mathrm{kg}) \\
& \mathrm{h}_{\text {ref }}=\text { enthalpy at reference temperature } \\
& \mathrm{T}_{\text {ref }}=\text { reference temperature }
\end{aligned}
$$

The calculated liquid enthalpies of biodiesels are plotted in figures 7, 8, and 9.

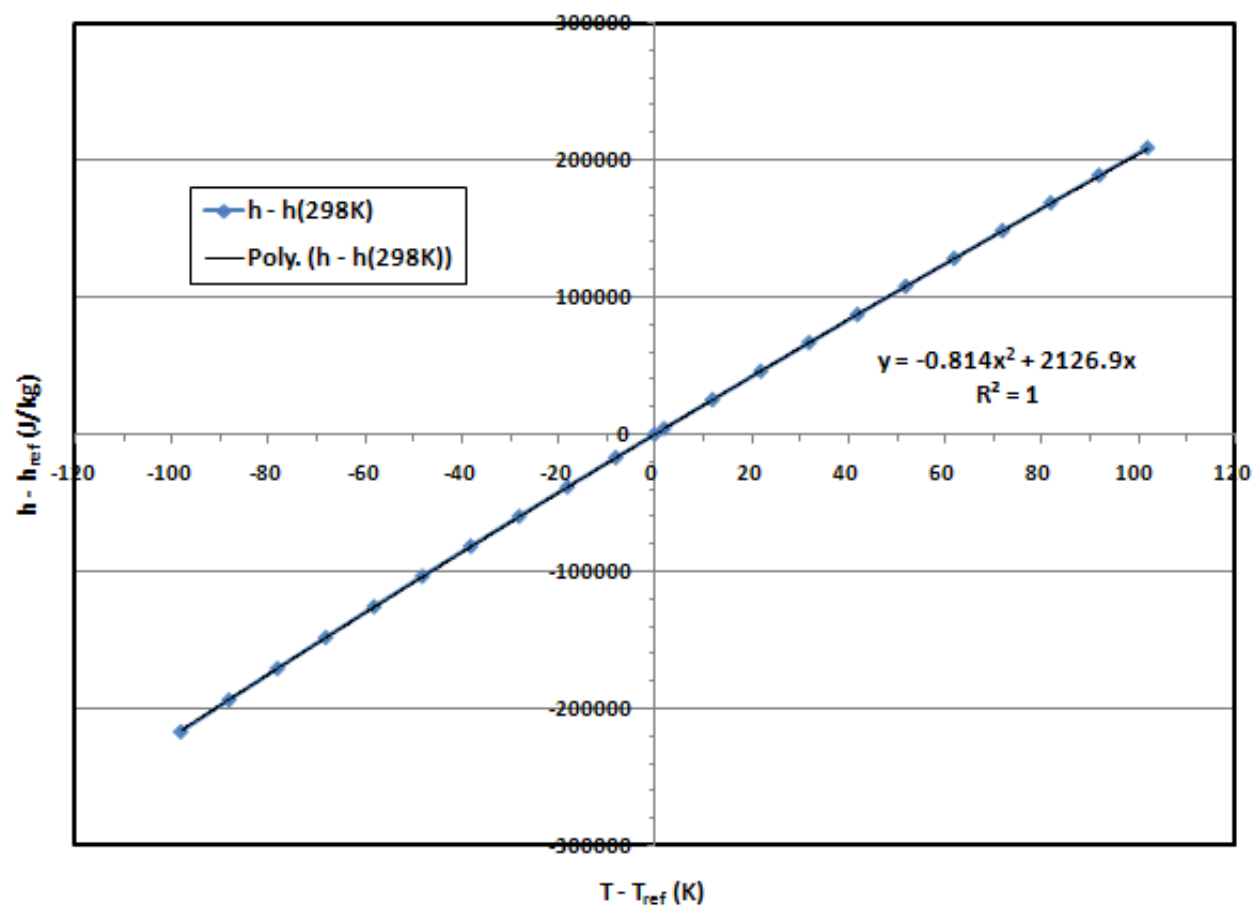

Figure 7. Liquid enthalpy of soybean methyl ester biodiesel (SME-11) 


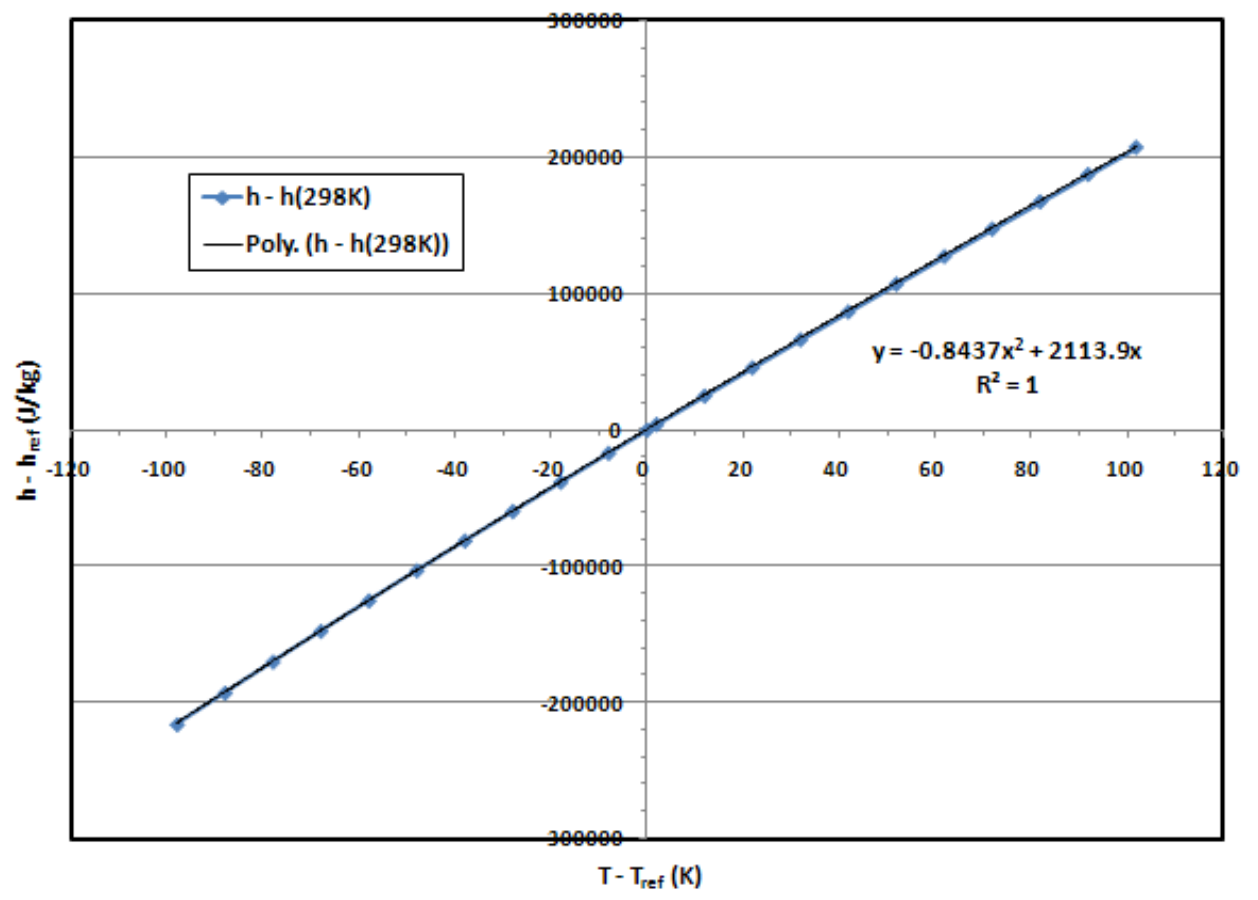

Figure 8. Liquid enthalpy of cottonseed methyl ester biodiesel (CME-11)

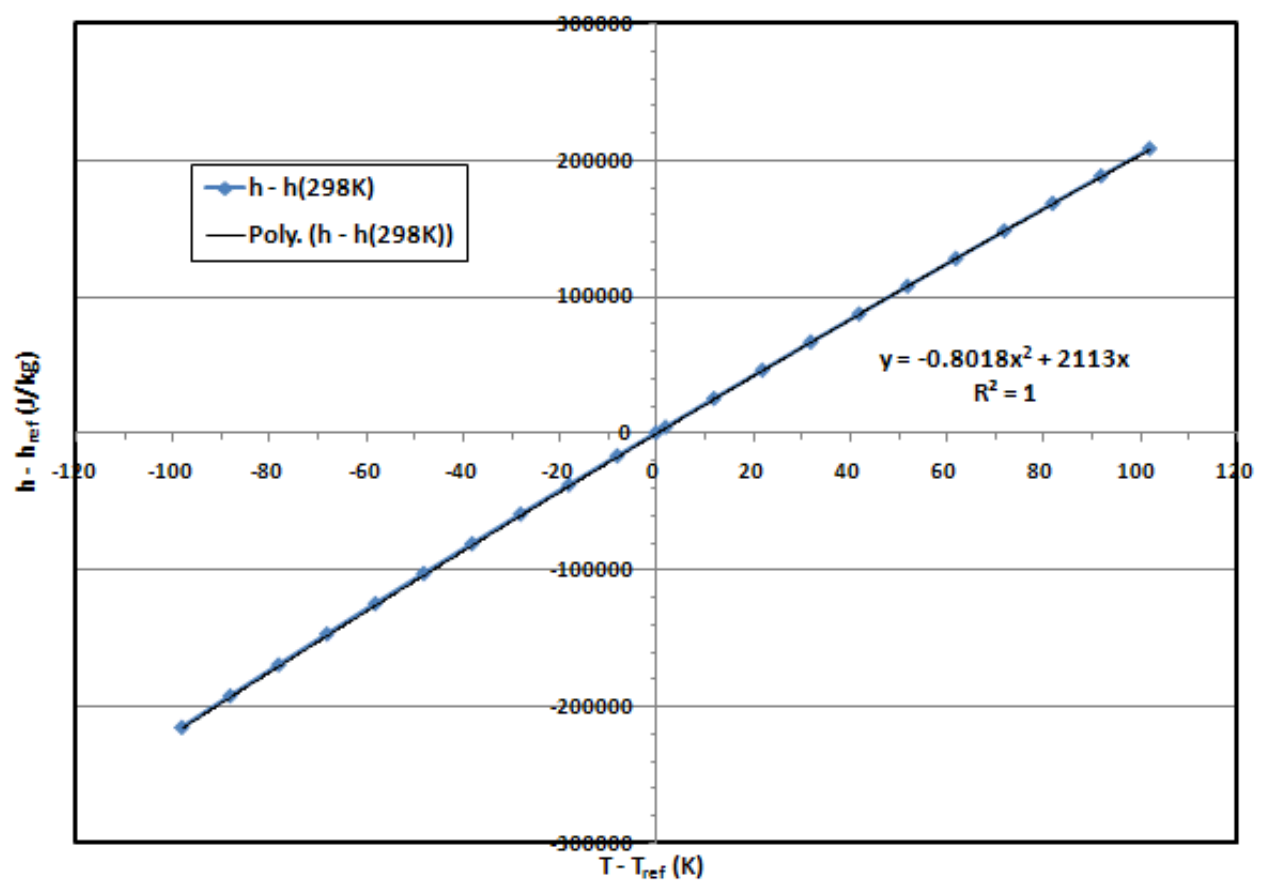

Figure 9. Liquid enthalpy of algae methyl ester biodiesel (AME-17) 
Lee-Kesler method [21] can be used to estimate the vapor heat capacity of pure gases as a function of temperature. This method is expressed by the following equation:

$$
\mathrm{C}_{\mathrm{p}}-\mathrm{C}_{\mathrm{p}}^{0}=\Delta \mathrm{C}_{\mathrm{p}}=\left(\Delta \mathrm{C}_{\mathrm{p}}\right)^{(0)}+\omega\left(\Delta \mathrm{C}_{\mathrm{p}}\right)^{(1)}
$$

Where

$\mathrm{C}_{\mathrm{p}}=$ heat capacity of vapor at constant pressure $(\mathrm{J} / \mathrm{mol}-\mathrm{K})$

$\mathrm{C}_{\mathrm{p}}{ }^{0}=$ heat capacity of vapor at a reference state $(\mathrm{J} / \mathrm{mol}-\mathrm{K})$

$\left(\Delta \mathrm{C}_{\mathrm{p}}\right)^{(0)}=$ simple fluid contribution as a function of reduced temperature and reduced pressure

$\left(\Delta \mathrm{C}_{\mathrm{p}}\right)^{(1)}=$ deviation function as a function of reduced temperature and reduced pressure

$\omega=$ Pitzer acentric factor

Joback method [21] uses group contributions to relate $\mathrm{C}_{\mathrm{p}}{ }^{0}$ to temperature. This method is represented by the following equation:

$$
\mathrm{C}_{\mathrm{p}}^{\mathrm{o}}=\left(\sum_{\mathrm{j}} \mathrm{n}_{\mathrm{j}} \Delta_{\mathrm{a}}-37.93\right)+\left(\sum_{\mathrm{j}} \mathrm{n}_{\mathrm{j}} \Delta_{\mathrm{b}}+0.210\right) \mathrm{T}+\left(\sum_{\mathrm{j}} \mathrm{n}_{\mathrm{j}} \Delta_{\mathrm{c}}-3.91 \times 10^{-4}\right) \mathrm{T}^{2}+\left(\sum_{\mathrm{j}} \mathrm{n}_{\mathrm{j}} \Delta_{\mathrm{d}}+2.06 \times 10^{-7}\right) \mathrm{T}^{3}
$$

Where

$\mathrm{n}_{\mathrm{j}}=$ number of groups of the "jth" type

$\Delta_{\mathrm{a}}, \Delta_{\mathrm{b}}, \Delta_{\mathrm{c}}, \Delta_{\mathrm{d}}=$ group contributions

$\mathrm{T}=$ temperature $(\mathrm{K})$

The group contributions related to the biodiesel fuels are shown in table 13 .

Table 13. Joback Group Contributions for Ideal-Gas Properties

\begin{tabular}{|c|c|c|c|c|}
\hline Group & $\begin{array}{c}\Delta_{\mathrm{a}} \\
(\mathrm{J} / \mathrm{mol}-\mathrm{K})\end{array}$ & $\begin{array}{c}\Delta_{\mathrm{b}} \\
(\mathrm{J} / \mathrm{mol}-\mathrm{K})\end{array}$ & $\begin{array}{c}\Delta_{\mathrm{C}} \\
(\mathrm{J} / \mathrm{mol}-\mathrm{K})\end{array}$ & $\begin{array}{c}\Delta_{\mathrm{d}} \\
(\mathrm{J} / \mathrm{mol}-\mathrm{K})\end{array}$ \\
\hline $\mathrm{CH}_{3}$ & $1.95 \mathrm{E}+01$ & $-8.08 \mathrm{E}-03$ & $1.53 \mathrm{E}-04$ & $-9.67 \mathrm{E}-08$ \\
\hline $\mathrm{CH}_{2}$ & $-9.09 \mathrm{E}-01$ & $9.50 \mathrm{E}-02$ & $-5.44 \mathrm{E}-05$ & $1.19 \mathrm{E}-08$ \\
\hline $\mathrm{CH}$ & -8 & $1.05 \mathrm{E}-01$ & $-9.63 \mathrm{E}-05$ & $3.56 \mathrm{E}-08$ \\
\hline $\mathrm{COO}$ & $2.45 \mathrm{E}+01$ & $4.02 \mathrm{E}-02$ & $4.02 \mathrm{E}-05$ & $-4.52 \mathrm{E}-08$ \\
\hline
\end{tabular}


Similar to the calculation of the liquid enthalpy, the biodiesel vapor heat capacity can also be integrated with respect to the temperature to get the vapor enthalpy. The calculated vapor enthalpies of biodiesels are plotted in figures 10,11 , and 12 .

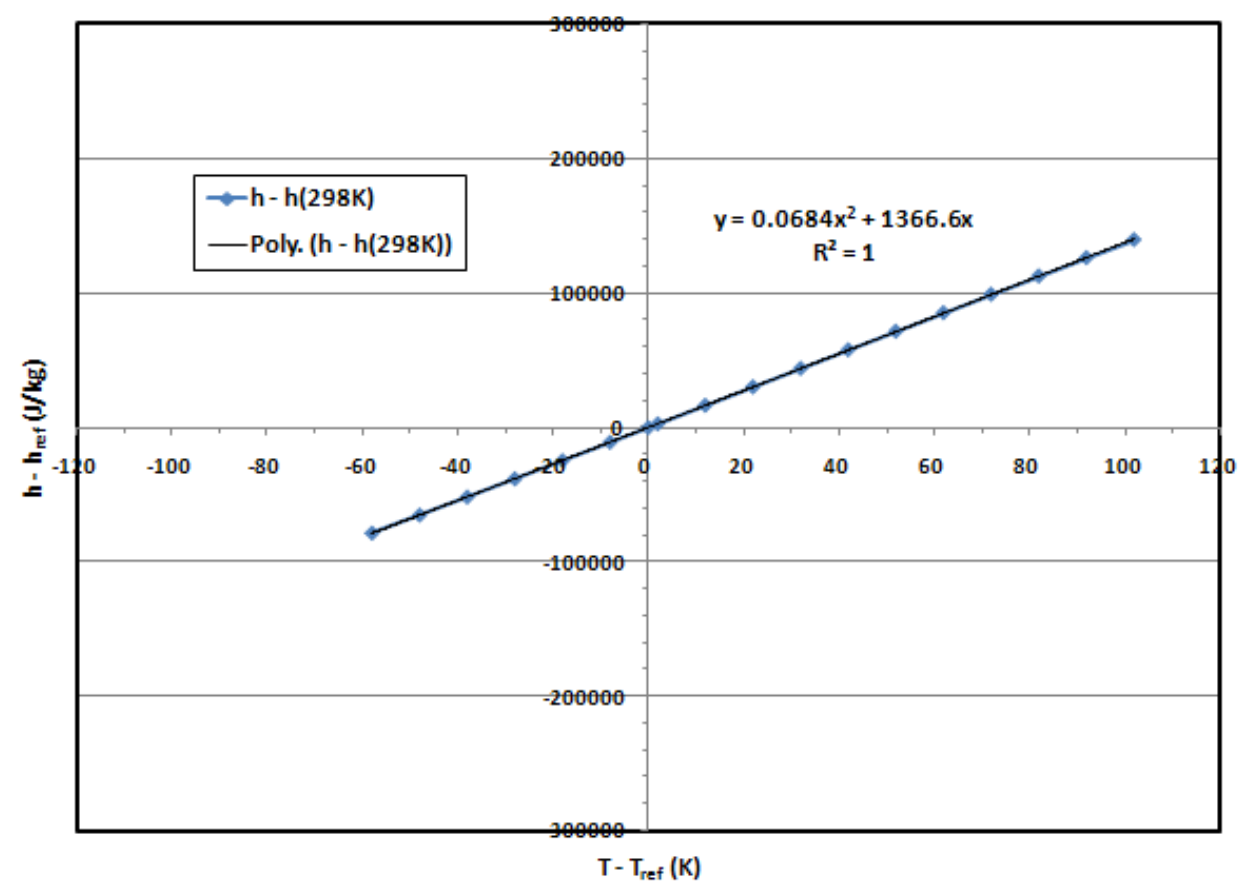

Figure 10. Vapor enthalpy of soybean methyl ester biodiesel (SME-11)

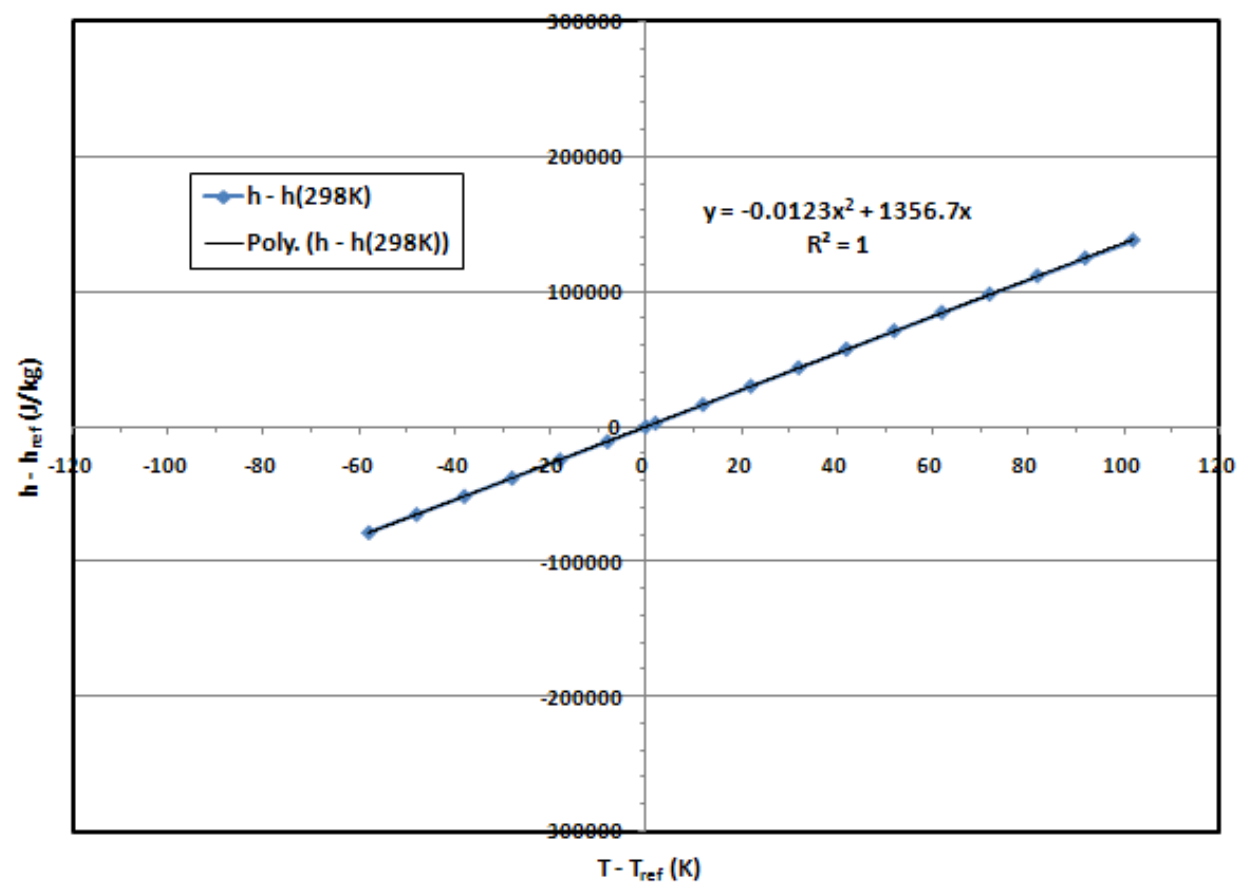

Figure 11. Vapor enthalpy of cottonseed methyl ester biodiesel (CME-11) 


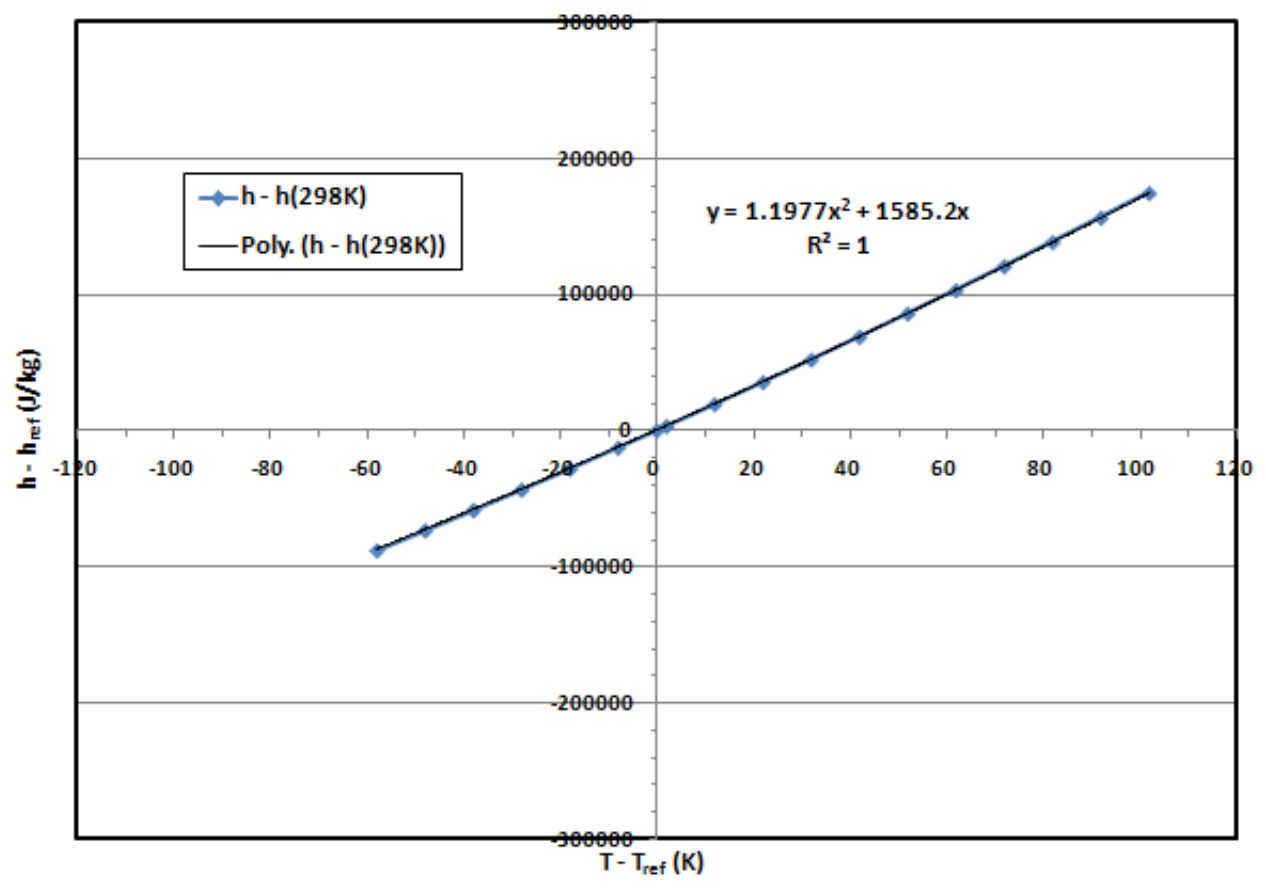

Figure 12. Vapor enthalpy of algae methyl ester biodiesel (AME-17)

The required GT-Power diesel and biodiesel fuel properties gathered, calculated, or estimated are now completed and summarized in tables 14 and 15.

Table 14. Diesel and biodiesel fuel properties required for GT-Power combustion simulations

\begin{tabular}{|c|c|c|c|c|c|}
\hline State & Properties & $\begin{array}{c}\text { No. } 2 \text { Diesel } \\
\text { (GT-Power Fuel } \\
\text { Library) }\end{array}$ & $\begin{array}{l}\text { Soybean } \\
\text { Methylester } \\
\text { (SME-11) }\end{array}$ & $\begin{array}{c}\text { Cottonseed } \\
\text { Methylester } \\
\text { (CME-11) }\end{array}$ & $\begin{array}{c}\text { Algae } \\
\text { Methylester } \\
\text { (AME-17) }\end{array}$ \\
\hline Liquid & $\begin{array}{c}\text { Heat of Vaporization } \\
\text { at } 25^{\circ} \mathrm{C}(\mathrm{kJ} / \mathrm{kg})\end{array}$ & 250 & 356.24 & 354.53 & 351.63 \\
\hline Liquid & $\begin{array}{c}\text { Density at } 25^{\circ} \mathrm{C} \\
\left(\mathrm{kg} / \mathrm{m}^{3}\right)\end{array}$ & 830 & 881.38 & 880.09 & 860.84 \\
\hline Liquid & $\begin{array}{l}\text { Enthalpy of Liquid } \\
\qquad(\mathrm{kJ} / \mathrm{kg})\end{array}$ & $\begin{array}{c}\text { GT-Power Fuel } \\
\text { Library }\end{array}$ & $\begin{array}{l}\text { Shown in } \\
\text { Table } 15\end{array}$ & $\begin{array}{l}\text { Shown in } \\
\text { Table } 15\end{array}$ & $\begin{array}{l}\text { Shown in } \\
\text { Table } 15\end{array}$ \\
\hline Liquid & $\begin{array}{l}\text { Kinematic Viscosity } \\
\text { of Liquid }\left(\mathrm{mm}^{2} / \mathrm{s}\right)\end{array}$ & $\begin{array}{c}\text { GT-Power Fuel } \\
\text { Library }\end{array}$ & $\begin{array}{l}\text { Shown in } \\
\text { Figure } 3\end{array}$ & $\begin{array}{l}\text { Shown in } \\
\text { Figure } 3\end{array}$ & $\begin{array}{c}\text { Shown in } \\
\text { Figure } 3\end{array}$ \\
\hline Liquid & $\begin{array}{c}\text { Thermal Conductivity } \\
\text { of Liquid }(\mathrm{W} /(\mathrm{mK}))\end{array}$ & $\begin{array}{c}\text { GT-Power Fuel } \\
\text { Library }\end{array}$ & $\begin{array}{l}\text { Shown in } \\
\text { Figure } 4\end{array}$ & $\begin{array}{l}\text { Shown in } \\
\text { Figure } 4\end{array}$ & $\begin{array}{c}\text { Shown in } \\
\text { Figure } 4\end{array}$ \\
\hline Vapor & $\begin{array}{l}\text { Lower Heating Value } \\
(\mathrm{kJ} / \mathrm{kg})\end{array}$ & 43250 & 37042 & 37500 & $37620^{*}$ \\
\hline Vapor & $\begin{array}{c}\text { Critical Temperature } \\
(\mathrm{K})\end{array}$ & 569.4 & 784.67 & 779.72 & 773.07 \\
\hline
\end{tabular}




\begin{tabular}{|l|c|c|c|c|c|} 
Vapor & Critical Pressure (bar) & 24.6 & 12.07 & 12.15 & 11.84 \\
\hline Vapor & $\begin{array}{c}\text { Enthalpy of Vapor } \\
(\mathrm{kJ} / \mathrm{kg})\end{array}$ & $\begin{array}{c}\text { GT-Power Fuel } \\
\text { Library }\end{array}$ & $\begin{array}{c}\text { Shown in } \\
\text { Table 15 }\end{array}$ & $\begin{array}{c}\text { Shown in } \\
\text { Table 15 }\end{array}$ & $\begin{array}{c}\text { Shown in } \\
\text { Table 15 }\end{array}$ \\
\hline Vapor & $\begin{array}{c}\text { Kinematic Viscosity } \\
\text { of Vapor }\left(\mathrm{mm}^{2} / \mathrm{s}\right)\end{array}$ & $\begin{array}{c}\text { GT-Power Fuel } \\
\text { Library }\end{array}$ & $\begin{array}{c}\text { Shown in } \\
\text { Figure 5 }\end{array}$ & $\begin{array}{c}\text { Shown in } \\
\text { Figure 5 }\end{array}$ & $\begin{array}{c}\text { Shown in } \\
\text { Figure 5 }\end{array}$ \\
\hline Vapor & $\begin{array}{c}\text { Thermal Conductivity } \\
\text { of Vapor (W/(m)) }\end{array}$ & $\begin{array}{c}\text { GT-Power Fuel } \\
\text { Library }\end{array}$ & $\begin{array}{c}\text { Shown in } \\
\text { Figure 6 } \\
\text { Atoms in Each } \\
\text { Molecule }\end{array}$ & $\begin{array}{c}\text { Shown in } \\
\text { Figure 6 }\end{array}$ & $\begin{array}{c}\text { Shown in } \\
\text { Figure 6 }\end{array}$ \\
\hline Vapor & $\begin{array}{c}\text { Number of Hydrogen } \\
\text { Atoms in Each } \\
\text { Molecule }\end{array}$ & 23.6 & 18.77 & 18.4732 & 18.6514 \\
\hline Vapor & $\begin{array}{c}\text { Number of Oxygen } \\
\text { Atoms in Each } \\
\text { Molecule }\end{array}$ & 0 & 34.4441 & 34.432 & 35.351 \\
\hline
\end{tabular}

Table 15. Enthalpy constants for liquid and vapor fuels required for GT-Power combustion simulations

\begin{tabular}{|c|c|c|c|c|c|}
\hline State & Enthalpy Constant & $\begin{array}{c}\text { No. 2 Diesel } \\
\text { (GT-Power } \\
\text { Fuel Library) }\end{array}$ & $\begin{array}{c}\text { Soybean } \\
\text { Methylester } \\
\text { (SME-11) }\end{array}$ & $\begin{array}{c}\text { Cottonseed } \\
\text { Methylester } \\
\text { (CME-11) }\end{array}$ & $\begin{array}{c}\text { Algae } \\
\text { Methylester } \\
\text { (AME-17) }\end{array}$ \\
\hline Liquid & $\mathrm{a}_{1}$ & 2050 & 2126.9 & 2113.9 & 2113 \\
\hline Liquid & $\mathrm{a}_{2}$ & 0 & -0.814 & -0.8437 & -0.8018 \\
\hline Liquid & $\mathrm{a}_{3}$ & 0 & 0 & 0 & 0 \\
\hline Vapor & $\mathrm{a}_{1}$ & 1634.3 & 1366.6 & 1356.7 & 1585.2 \\
\hline Vapor & $\mathrm{a}_{2}$ & 1.8191 & 0.0684 & -0.0123 & 1.1977 \\
\hline Vapor & $\mathrm{a}_{3}$ & 0 & 0 & 0 & 0 \\
\hline Vapor & $\mathrm{a}_{4}$ & 0 & 0 & 0 & 0 \\
\hline Vapor & $\mathrm{a}_{5}$ & 0 & 0 & 0 & 0 \\
\hline
\end{tabular}

\section{4-COMBUSTION EMISSIONS SIMULATIONS}

A four-stroke single cylinder direct injection diesel engine was used for biodiesel emissions simulations and testing in this study. The test engine specifications are listed in table 16. The measured intake and exhaust valve lift curves are shown in figure 13, in which the zero-degree and 180-degree crank angles are the top dead center (TDC) and bottom dead center (BDC), respectively.

Table 16. Specifications of diesel engine used in emissions testing

\begin{tabular}{|l|l|}
\hline Engine Type & Single-Cylinder, 4-Cycle, Air-Cooled Diesel Engine \\
\hline Combustion System & Direct Injection System \\
\hline Bore & $86 \mathrm{~mm}$ \\
\hline
\end{tabular}




\begin{tabular}{|l|l|}
\hline Stroke & $70 \mathrm{~mm}$ \\
\hline Displacement Volume & $406 \mathrm{~cm}^{3}$ \\
\hline Continuous Output & $6.6 \mathrm{~kW}$ \\
\hline Rated Speed & $3600 \mathrm{RPM}$ \\
\hline Compression Ratio & 19.3 \\
\hline Fuel Injection Pressure & $196 \mathrm{bar}$ \\
\hline
\end{tabular}

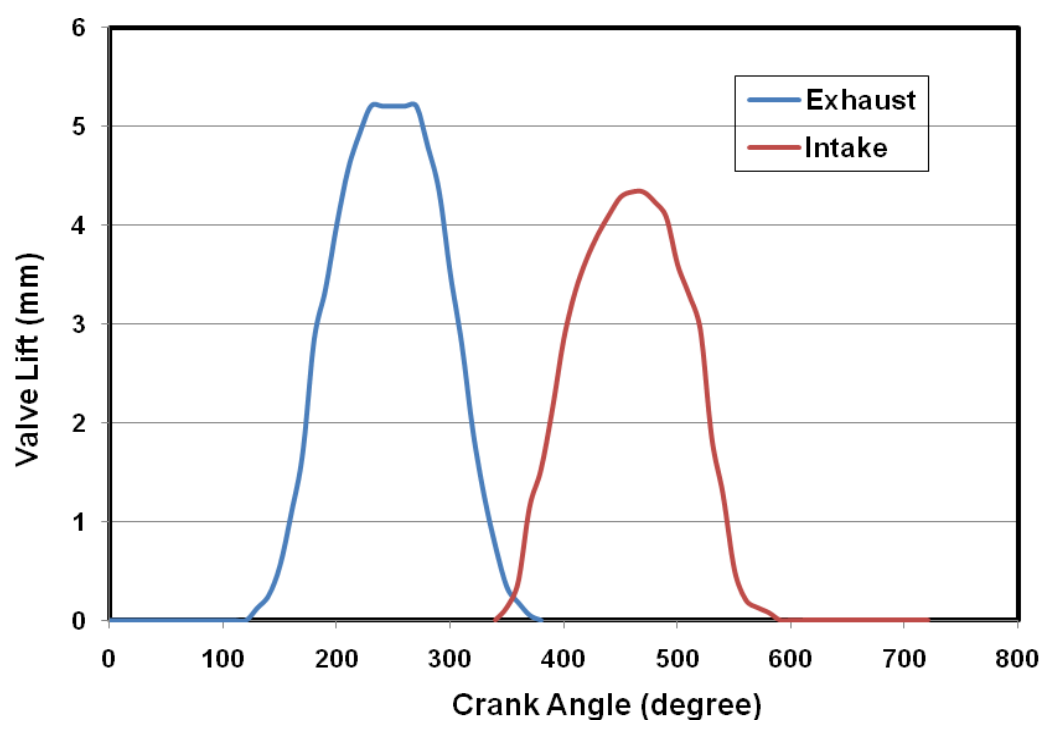

Figure 13. Measured valve lift curves of diesel engine used in emissions testing

Using fuel properties of the biodiesels of interest (listed in tables 14 and 15), estimated from constituent data, initial GT-Power combustion simulations of the soybean, cottonseed, and algae methyl esters were performed to predict the biodiesel combustion emissions. The testing parameters, which included an engine speed of $2200 \mathrm{RPM}$, an injected fuel mass per cycle of $9.7 \mathrm{mg}$, and an assumed fuel injector sac pressure profile, used in an initial No. 2 diesel benchmarking exercise were also used in this biodiesel combustion emissions evaluation. The predicted emissions concentrations of the No. 2 diesel and biodiesel fuels are summarized in table 17.

Table 17. Predicted combustion emissions (engine speed $=2200$ RPM, fuel mass per cycle $=9.7 \mathrm{mg}$ )

\begin{tabular}{|c|c|c|c|c|}
\hline Fuel & $\begin{array}{c}\text { NOx } \\
(\mathrm{ppm})\end{array}$ & $\begin{array}{c}\mathrm{CO} \\
(\mathrm{ppm})\end{array}$ & $\begin{array}{c}\mathrm{HC} \\
(\mathrm{ppm})\end{array}$ & $\begin{array}{c}\mathrm{CO} 2 \\
(\mathrm{ppm})\end{array}$ \\
\hline No. 2 Diesel & 153 & 1837 & 26.6 & 56930 \\
\hline $\begin{array}{c}\text { Soybean } \\
\text { Methylester }\end{array}$ & 164 & 994 & 9.9 & 51746 \\
\hline $\begin{array}{c}\text { Cottonseed } \\
\text { Methylester }\end{array}$ & 177 & 924 & 8.9 & 51607 \\
\hline
\end{tabular}




\begin{tabular}{|c|c|c|c|c|}
$\begin{array}{c}\text { Algae } \\
\text { Methylester }\end{array}$ & 183 & 748 & 7.5 & 51764 \\
\hline
\end{tabular}

The emission impacts of the biodiesel fuel can be examined by comparing the biodiesel emissions concentrations with those of the No. 2 diesel. Based on the predicted emissions concentrations shown in the table 17, emissions changes for the 100\% biodiesels (B100), as compared to the No. 2 diesel emissions, are included in table 18. The predicted average percent changes of B100 biodiesel combustion emissions are $+14.2 \%$ for $\mathrm{NO}_{\mathrm{x}},-51.6 \%$ for $\mathrm{CO},-67 \%$ for $\mathrm{HC}$, and $-9.2 \%$ for $\mathrm{CO}_{2}$.

Table 18. Percent changes in B100 biodiesel (100\% biodiesel) emissions as compared to No. 2 diesel emissions

\begin{tabular}{|c|c|c|c|c|}
\hline Fuel & $\begin{array}{c}\mathrm{NOx} \\
(\mathrm{ppm})\end{array}$ & $\begin{array}{c}\mathrm{CO} \\
(\mathrm{ppm})\end{array}$ & $\begin{array}{c}\mathrm{HC} \\
(\mathrm{ppm})\end{array}$ & $\begin{array}{c}\mathrm{CO} 2 \\
(\mathrm{ppm})\end{array}$ \\
\hline $\begin{array}{c}\text { Soybean } \\
\text { Methylester }\end{array}$ & $+7.2 \%$ & $-45.9 \%$ & $-62.8 \%$ & $-9.1 \%$ \\
\hline $\begin{array}{c}\text { Cottonseed } \\
\text { Methylester }\end{array}$ & $+15.7 \%$ & $-49.7 \%$ & $-66.5 \%$ & $-9.4 \%$ \\
\hline $\begin{array}{c}\text { Algae } \\
\text { Methylester }\end{array}$ & $+19.6 \%$ & $-59.3 \%$ & $-71.8 \%$ & $-9.1 \%$ \\
\hline Average & $+14.2 \%$ & $-51.6 \%$ & $-67 \%$ & $-9.2 \%$ \\
\hline
\end{tabular}

A number of studies have examined the emission impacts of biodiesel in 4-stroke direct injection diesel engines and 2-stroke indirect injection engines. These studies have been reviewed by the U.S. Environmental Protection Agency (EPA) [24] with statistical analysis. Figure 14, taken from the EPA report and the U.S. National Renewable Energy Laboratory (NREL) report [25], shows the overall trends with biodiesel blending level for four regulated pollutants of $\mathrm{NO}_{\mathrm{x}}, \mathrm{PM}, \mathrm{CO}$, and $\mathrm{HC}$. Referring to figure 14 , for a B100 biodiesel, the reported percent changes in pollutant emissions are approximately $+10 \%$ for $\mathrm{NO}_{\mathrm{x}},-48.5 \%$ for $\mathrm{CO}$, and $-67 \%$ for $\mathrm{HC}$.

The biodiesel percent changes in emissions, predicted by the GT-Power simulations, shown in the table 18 agree well with those test data shown in the figure 14 . It should be noted that these biodiesel combustion simulations were based on an assumed fuel injector sac pressure profile used in a predictive GT-Power combustion model. However, although the absolute values of the predicted combustion emissions will likely change when the actual fuel injector sac pressure profiles are used in the GT-Power simulations, this biodiesel emissions evaluation using the calculated or estimated biodiesel fuel properties shown in the tables 14 and 15 does show the correct trends of the emission impacts of the biodiesel fuel. 


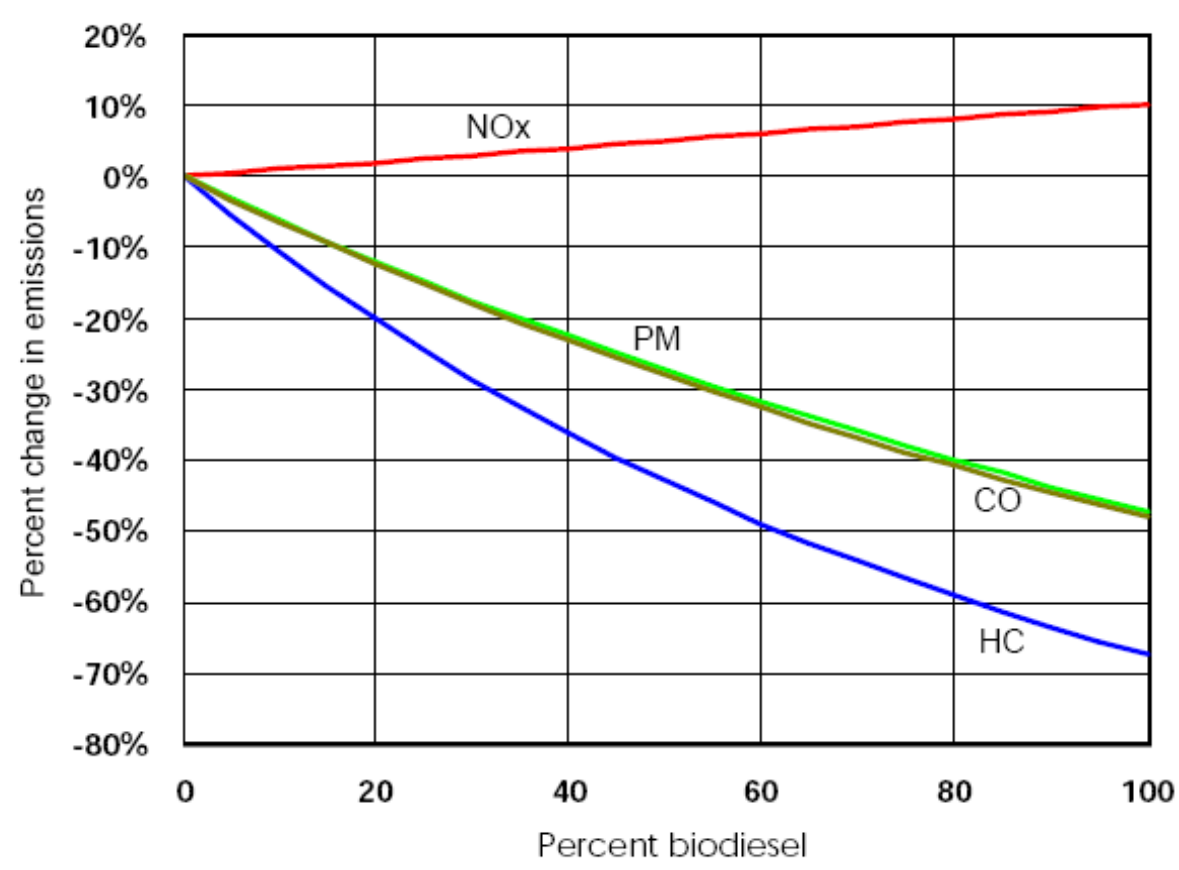

Figure 14. Trends in percentage change in pollutant emissions with biodiesel content as estimated from published engine dynamometer data in the EPA study [24, 25]

\section{5-COMBUSTION EMISSIONS TESTING}

With the fuel pump system that the test engine uses, two absolute pressure transducers in a pressure range of approximately 2000 bar were used to measure fuel pressures at two different points, fuel pump end and nozzle holder end, along the injection line. The pressure and velocity in the injector sac area were computationally determined by the pressures measured at these two points. Two AVL high-pressure transducers (SL31D-2000), with a measuring range of 0 to 2000 bar, and AVL data acquisition system analysis software of IndiSignal and Concerto were used to measure the fuel injector sac pressure profile. The AVL pressure sensors were installed at the ends of the injection line, one at the fuel pump end and the other at the nozzle holder end [4].

During biodiesel emissions testing, in-cylinder pressure traces, cylinder pressure versus crank angle, were measured and compared to the cylinder pressure profiles predicted by the combustion simulations. A pressure bore was drilled into the cylinder head and threaded to hold a Kistler high-temperature pressure transducer for the measurement of such cylinder pressure traces.

The diesel engine exhaust emissions were measured by a $\mathrm{NO}_{\mathrm{x}}$ sensor connected to a MEXA 720-NO emissions analyzer and a $\mathrm{HC} / \mathrm{CO} / \mathrm{CO}_{2}$ sensor connected to a MEXA 554-JU emissions analyzer. These emissions sensors were fully calibrated prior to the testing. A schematic diagram of the experimental setup is shown in figure 15. 


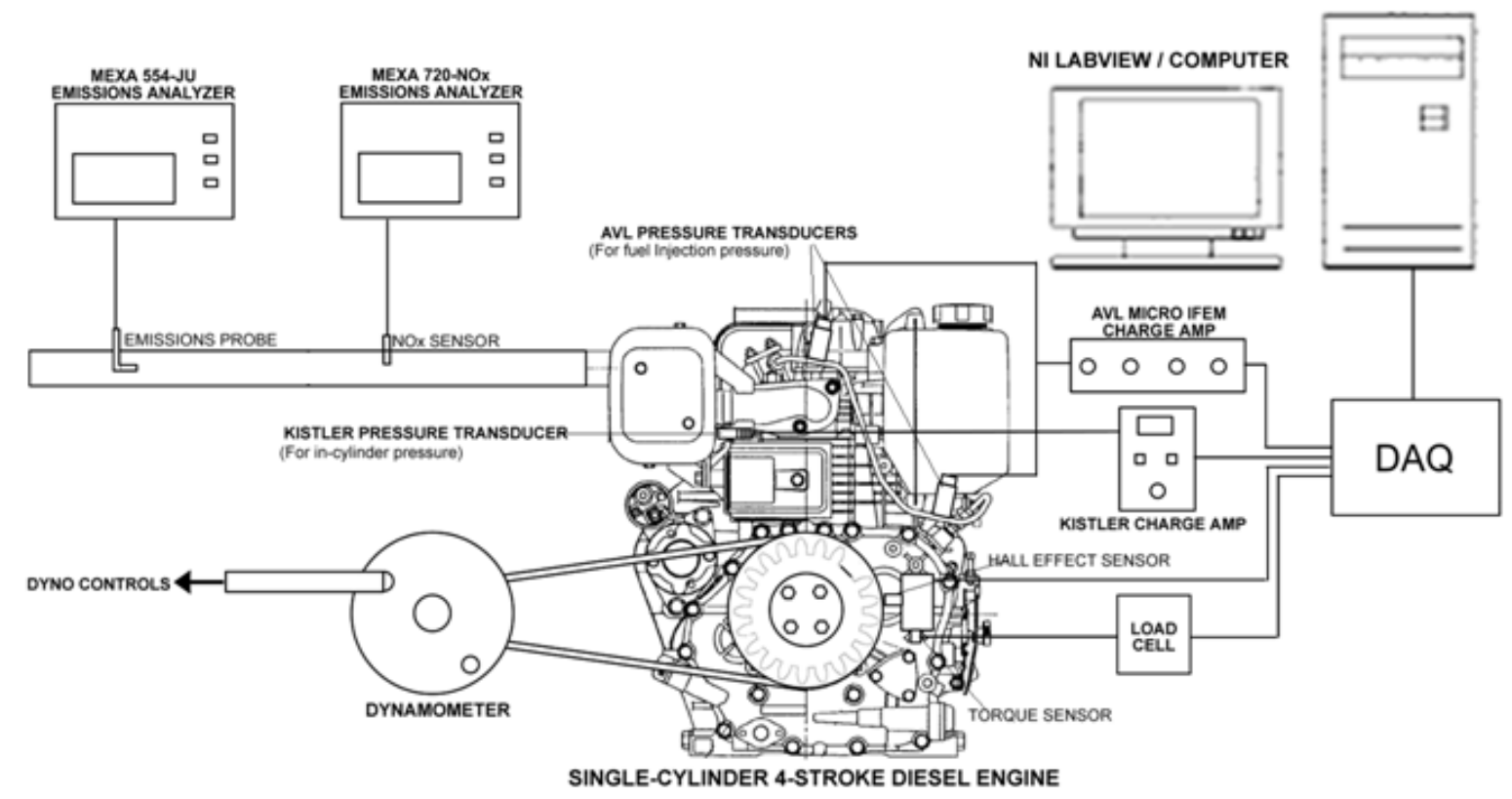

Figure 15. Schematic diagram of experimental setup

\section{6-RESULTS AND DISCUSSION}

Since the neat soybean biodiesel is commercially available, engine emissions, which include $\mathrm{NO}_{\mathrm{x}}, \mathrm{HC}$, $\mathrm{CO}$ and $\mathrm{CO}_{2}$, of this particular biodiesel have been measured during laboratory combustion emissions testing at various engine speed-load combinations and the measured B100 soybean biodiesel emissions were compared to those predicted by the combustion simulations. The combustion emissions tests were conducted at two engine speeds of 2200 and 2600 RPM. Four different loads of 2.5, 5, 7.5, and10 Nm were applied to the test engine at each speed. The measured in-cylinder pressure profiles and fuel injector sac pressure profiles of these emissions tests are shown in figures 16, 17, 18 and 19. 


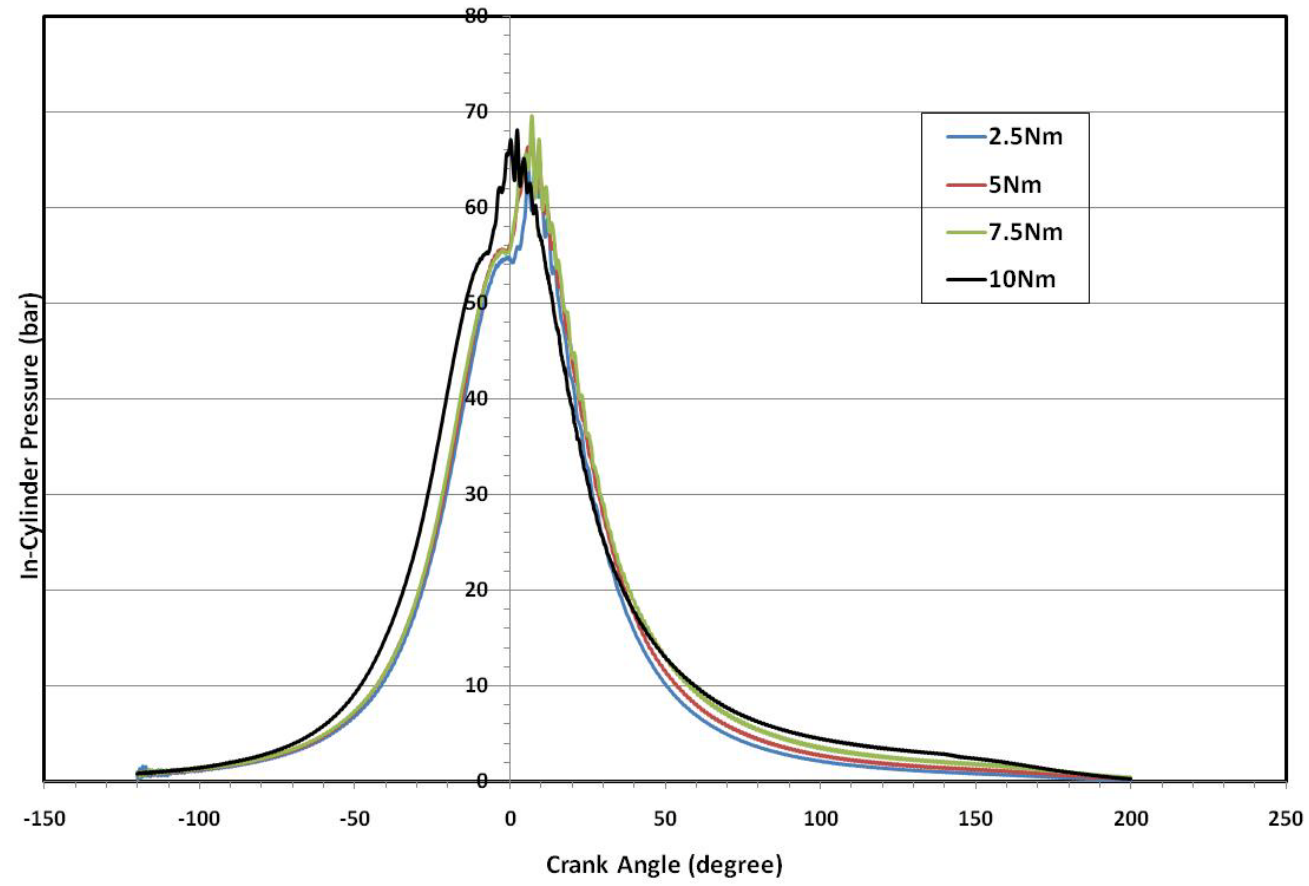

Figure 16. Measured in-cylinder pressure profiles at engine speed of 2200 RPM under engine loads of 2.5/5/7.5/10 Nm (B100 soybean biodiesel fuel)

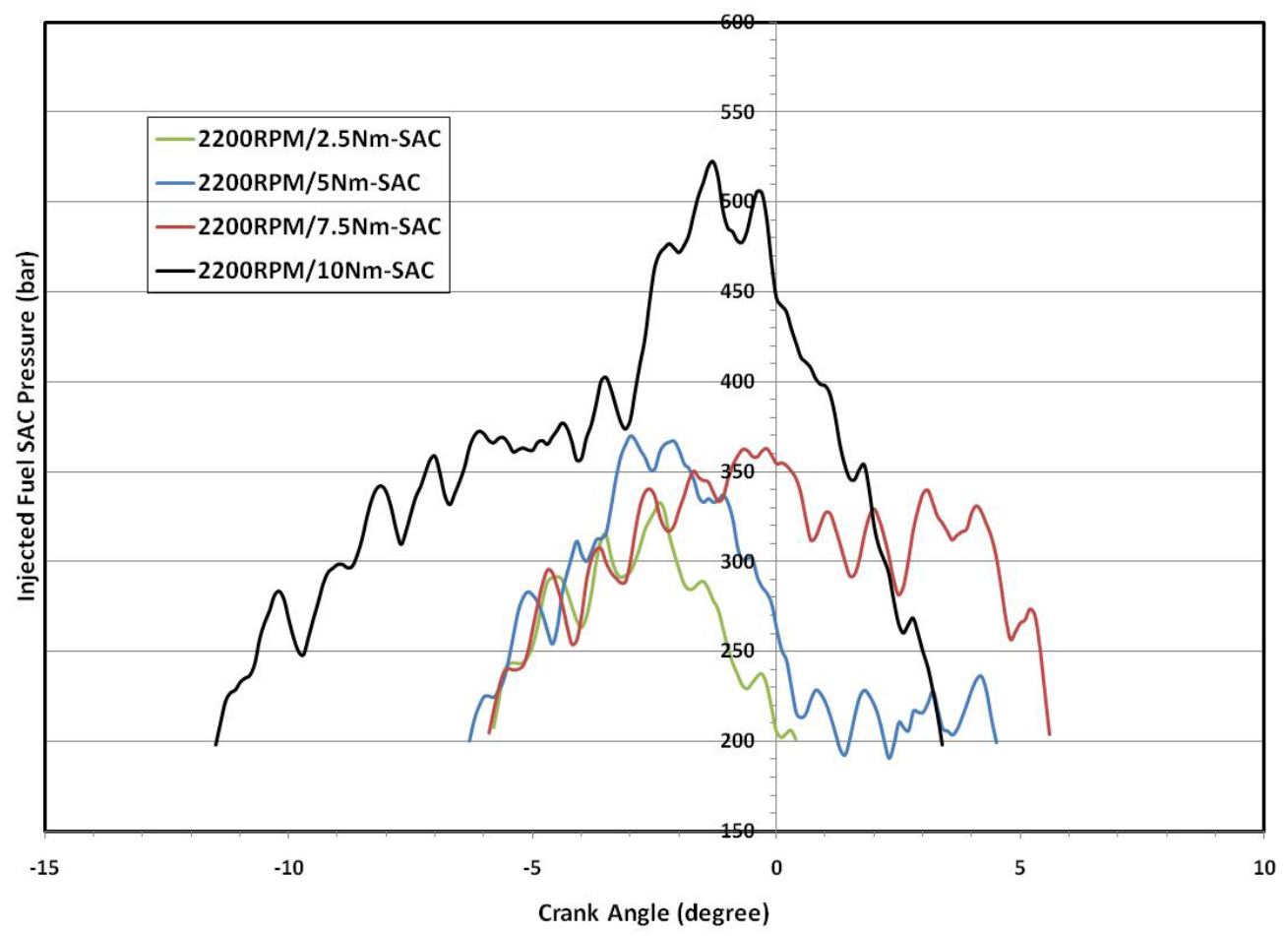

Figure 17. Measured fuel injector sac pressure profiles at engine speed of 2200 RPM under engine loads of 2.5/5/7.5/10 Nm (B100 soybean biodiesel fuel) 


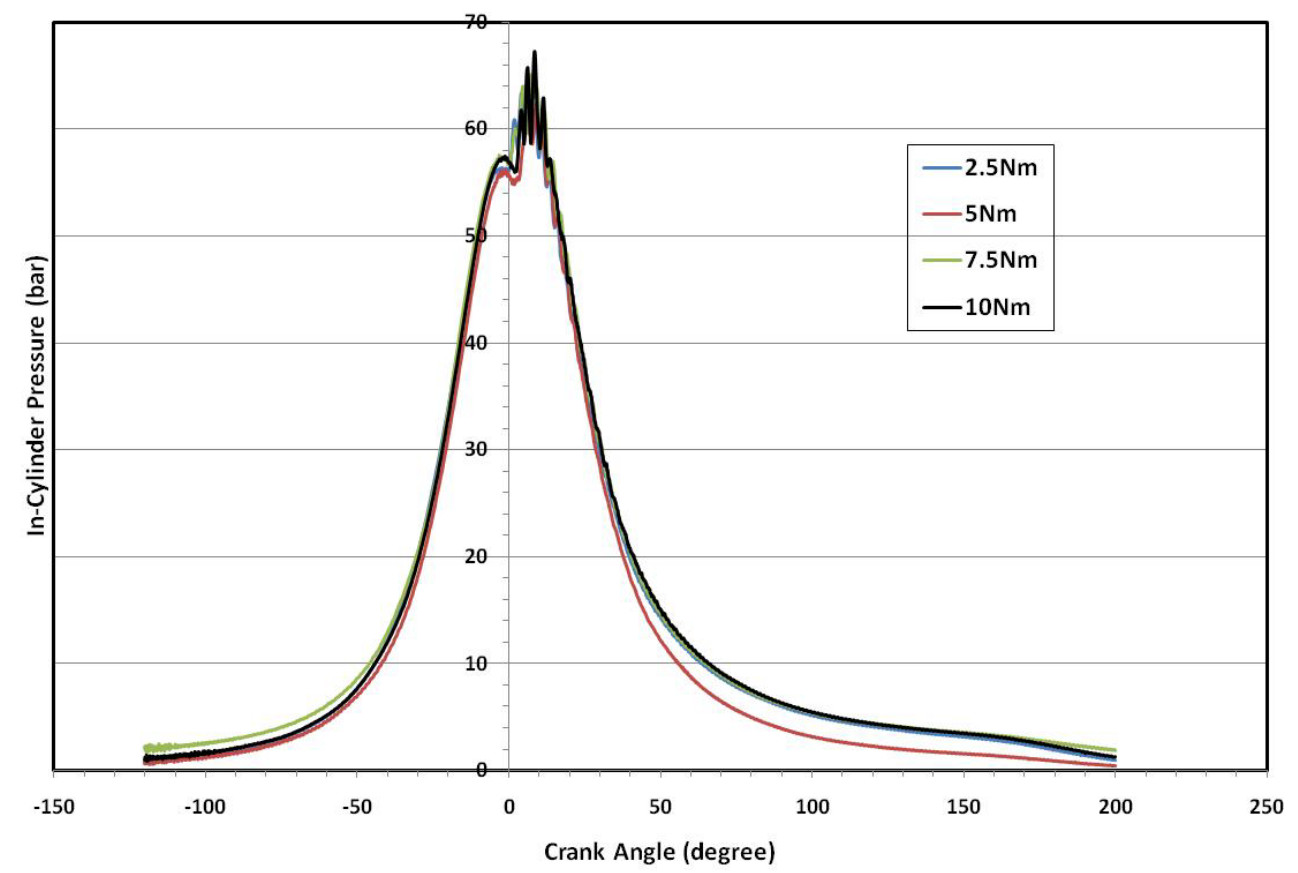

Figure 18. Measured in-cylinder pressure profiles at engine speed of 2600 RPM under engine loads of 2.5/5/7.5/10 Nm (B100 soybean biodiesel fuel)

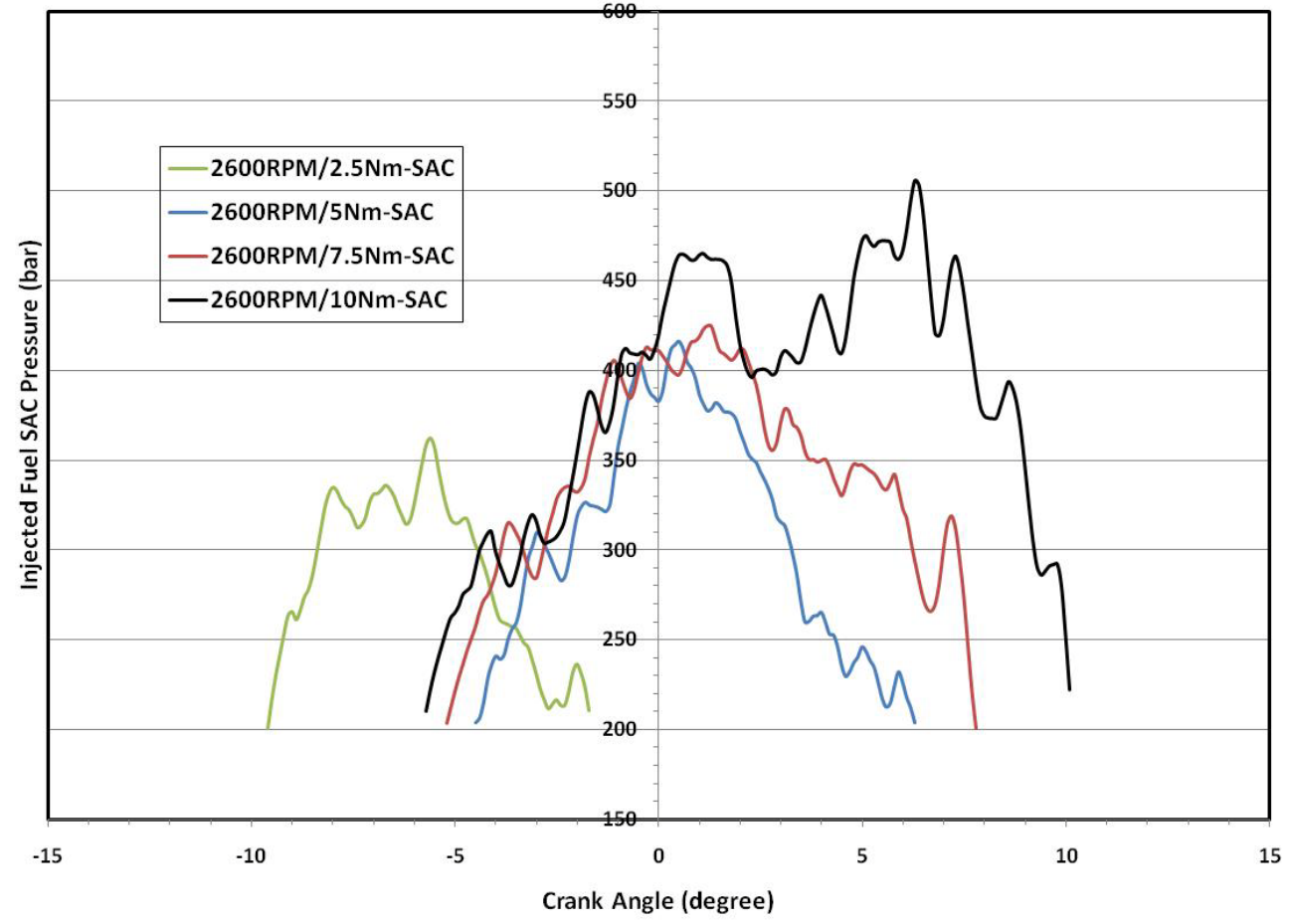

Figure 19. Measured fuel injector sac pressure profiles at engine speed of 2600 RPM under engine loads of 2.5/5/7.5/10 Nm (B100 soybean biodiesel fuel) 
The fuel injector sac pressure profiles shown in figures 17 and 19 were used as modeling inputs in the GT-Power combustion simulations. Fuel injection quantities per cycle required in the GT-Power simulations were determined by performing numerical integrations on the Concerto-measured fuel injection rate profiles. The simulation-predicted cylinder pressure profiles are compared with those measured in the emissions tests at various engine speeds and engine loads. Figures 20 to 23 show the incylinder pressure comparison for the B100 soybean biodiesel fuel between simulation predictions and test measurements at engine speeds of 2200 and 2600 RPM under engine loads of 5 and $7.5 \mathrm{Nm}$. As shown in figures 20 to 23, the predicted and measured cylinder pressure profiles agree well for the emissions simulations performed and tests conducted.

The GT-Power simulations also predicted some combustion parameters that were difficult to measure in the emissions tests, such as cylinder temperature and heat release rate profiles. Figures 24 to 29 show the simulation-predicted profiles of cylinder temperature, apparent heat release rate, and $\mathrm{NO}_{\mathrm{x}}$ concentration, resulted from B100 soybean biodiesel fuel combustion in the test engine at the described engine speeds and loads.

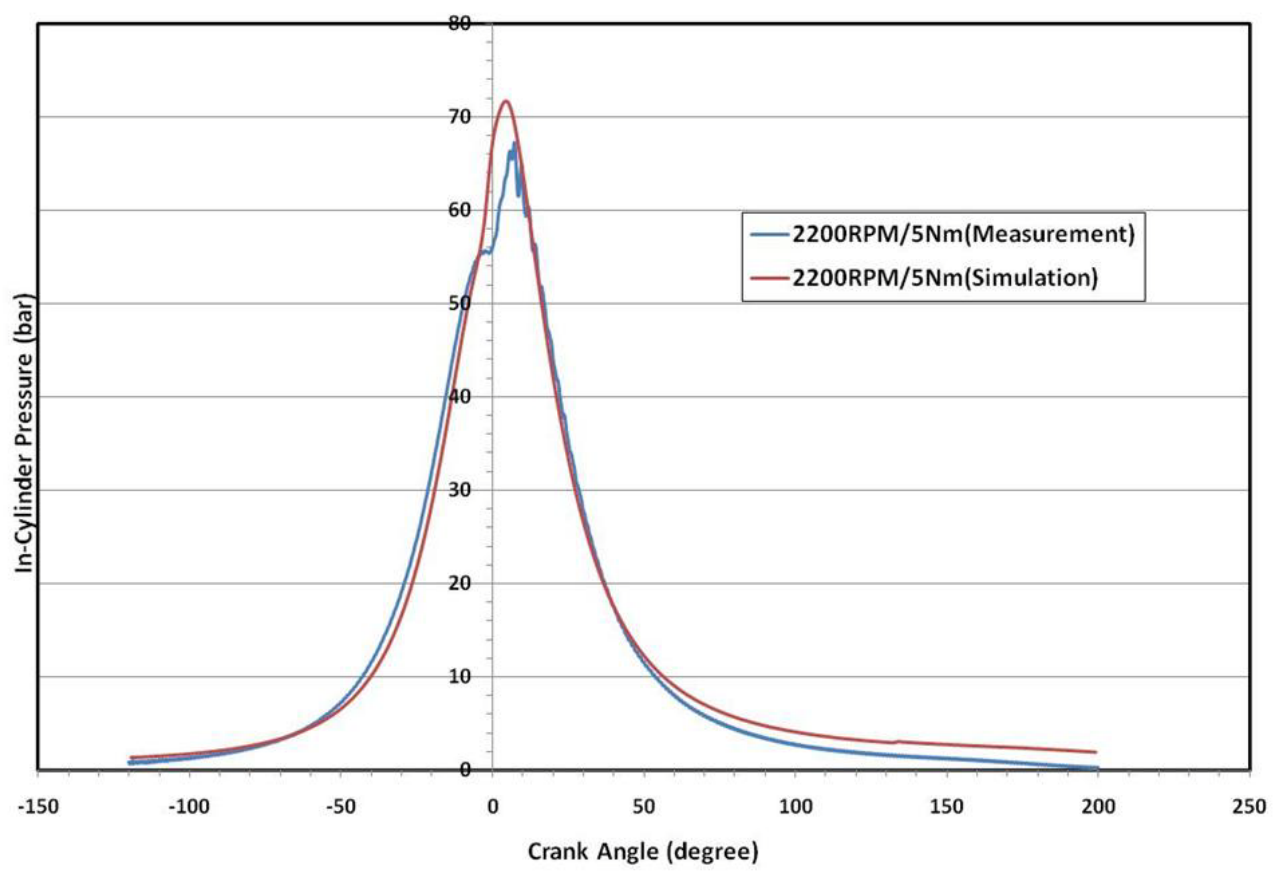

Figure 20. Predicted and measured in-cylinder pressure profiles at engine speed of 2200 RPM and engine load of $5 \mathrm{Nm}$ (B100 soybean biodiesel fuel) 


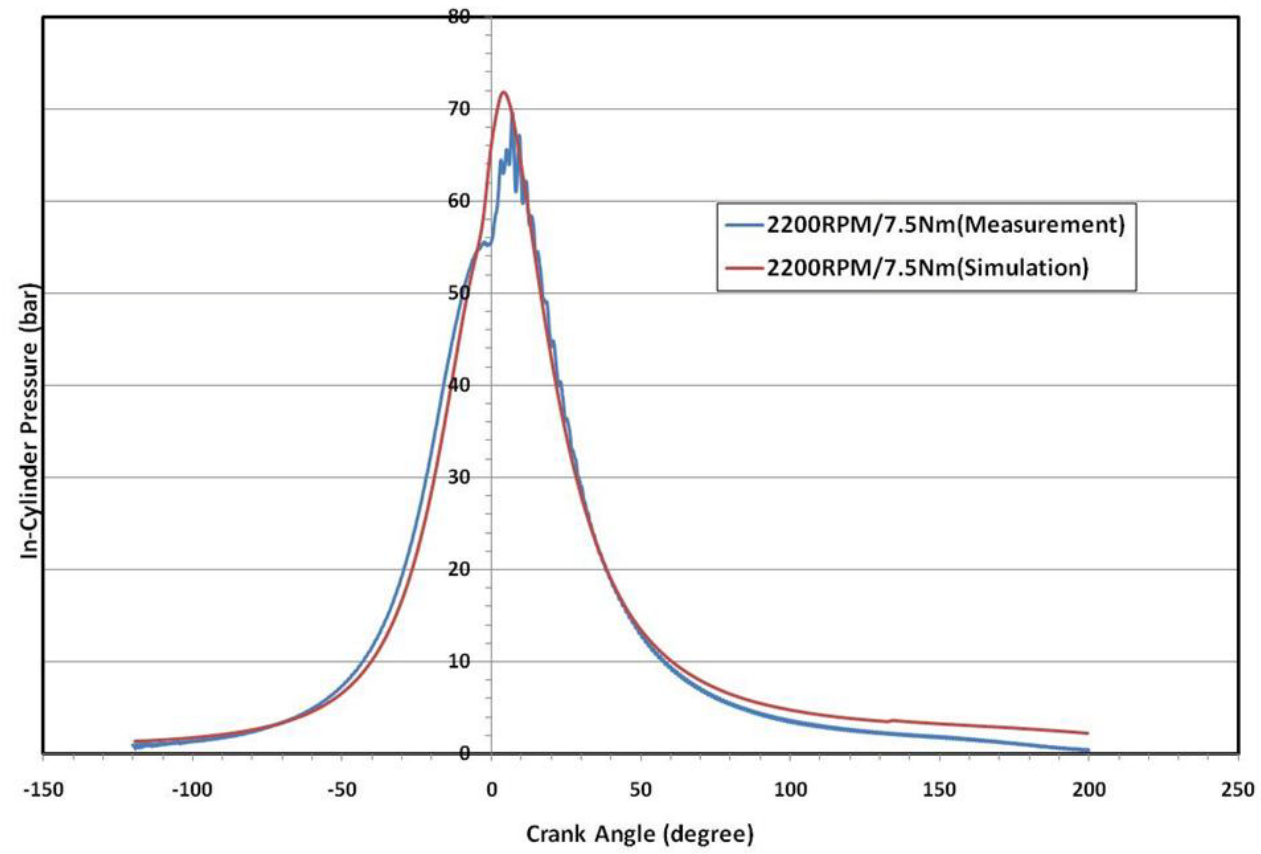

Figure 21. Predicted and measured in-cylinder pressure profiles at engine speed of 2200 RPM and engine load of 7.5 Nm (B100 soybean biodiesel fuel)

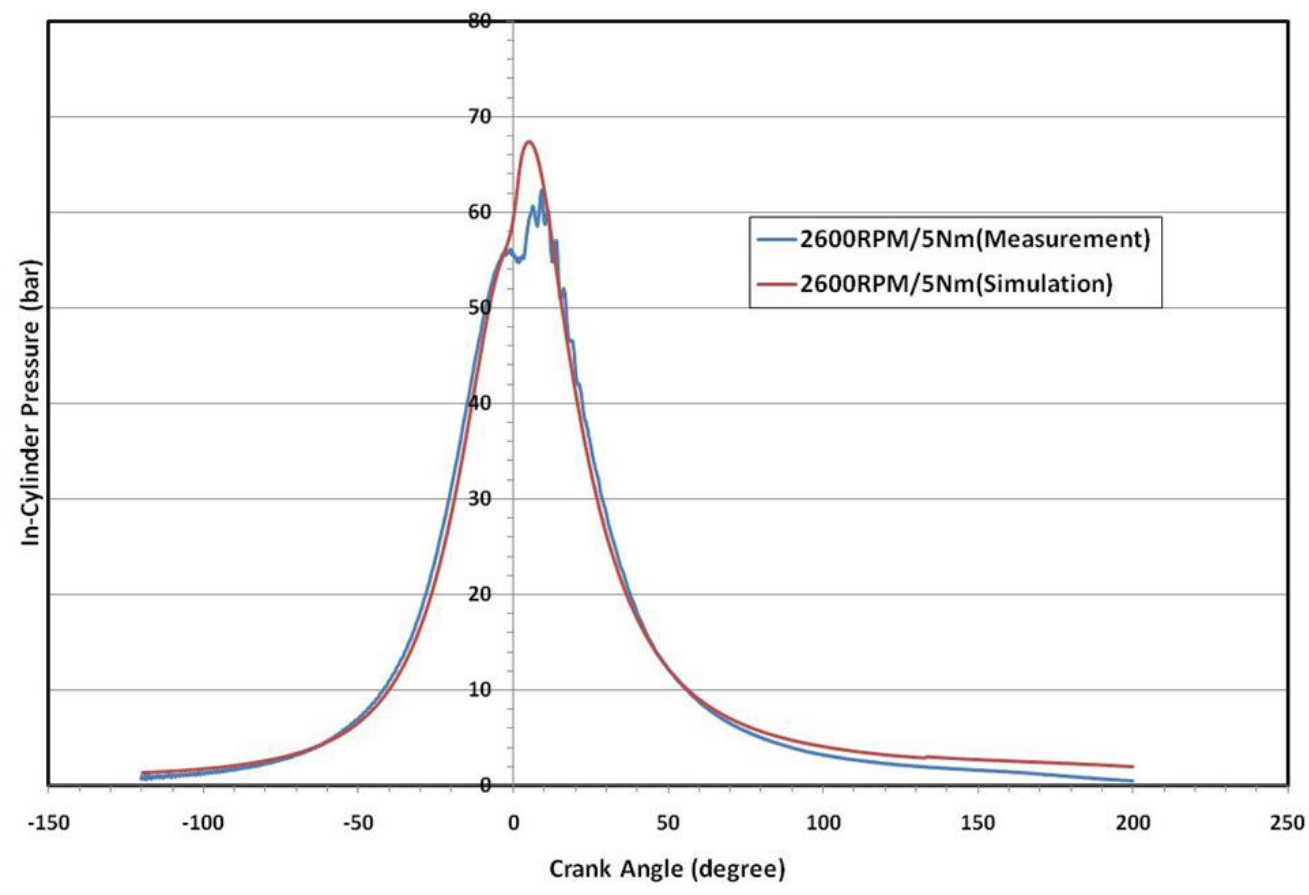

Figure 22. Predicted and measured in-cylinder pressure profiles at engine speed of 2600 RPM and engine load of $5 \mathrm{Nm}$ (B100 soybean biodiesel fuel) 


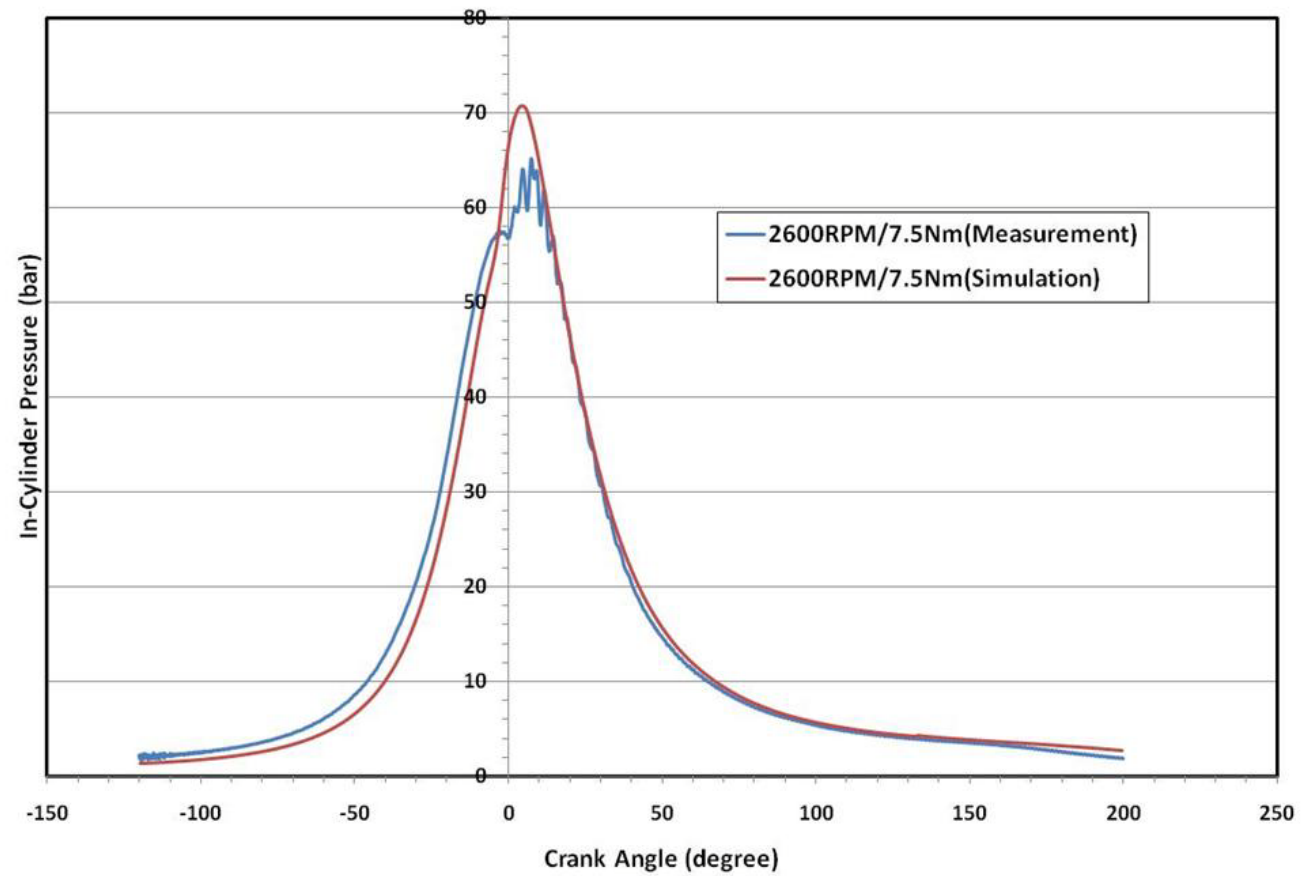

Figure 23. Predicted and measured in-cylinder pressure profiles at engine speed of 2600 RPM and engine load of 7.5 Nm (B100 soybean biodiesel fuel)

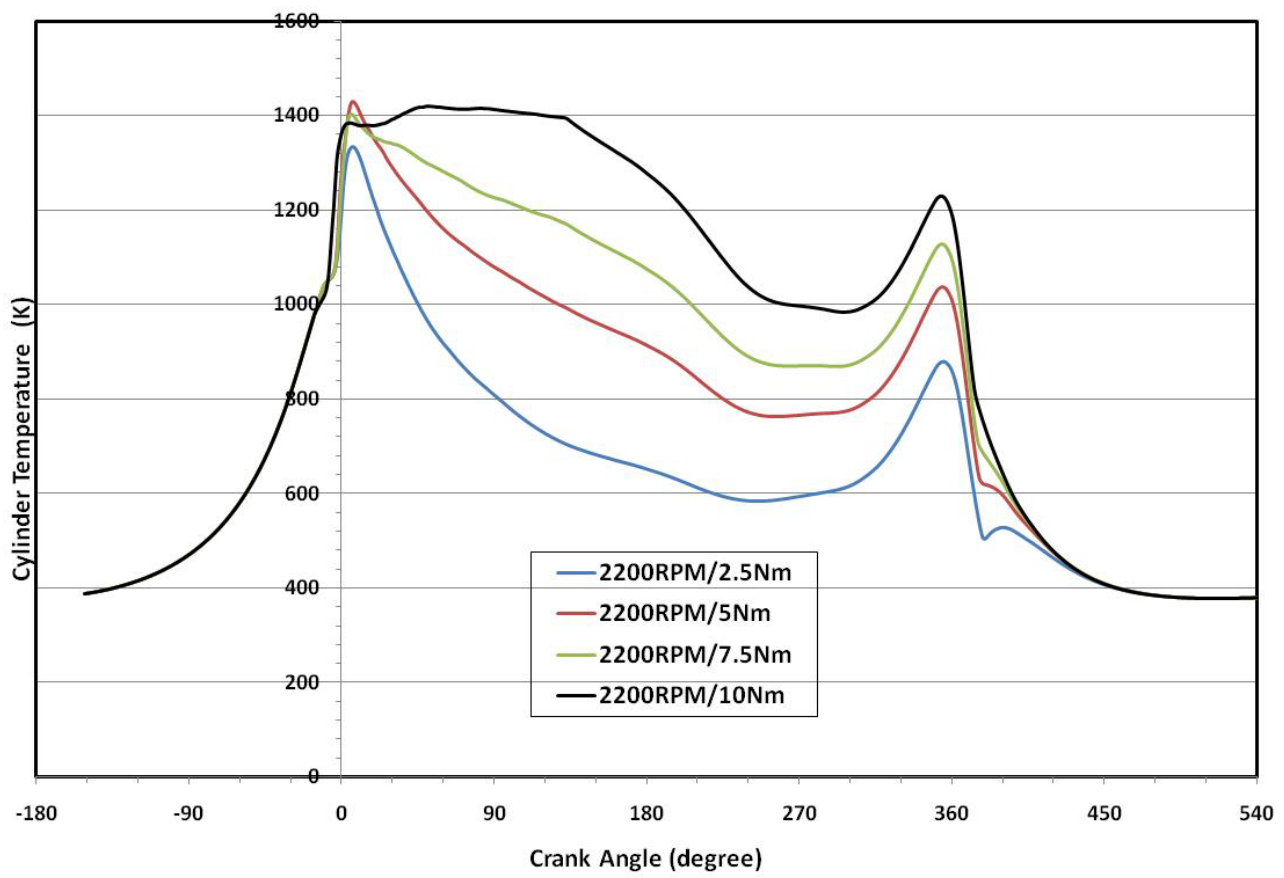

Figure 24. Simulation-predicted cylinder temperature at engine speed of 2200 RPM and engine loads of 2.5/5/7.5/10 Nm (B100 soybean biodiesel fuel) 


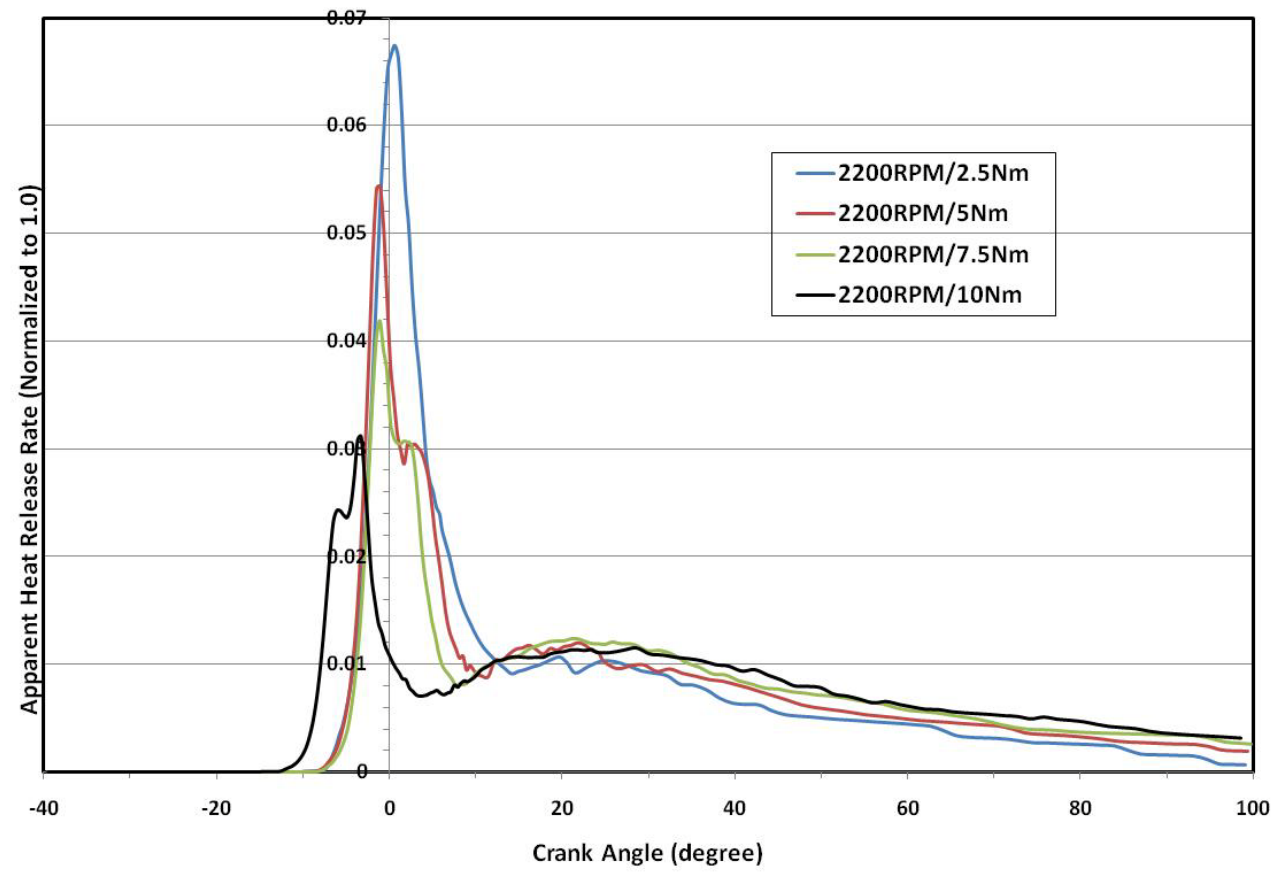

Figure 25. Simulation-predicted apparent heat release rate at engine speed of 2200 RPM and engine loads of 2.5/5/7.5/10 Nm (B100 soybean biodiesel fuel)

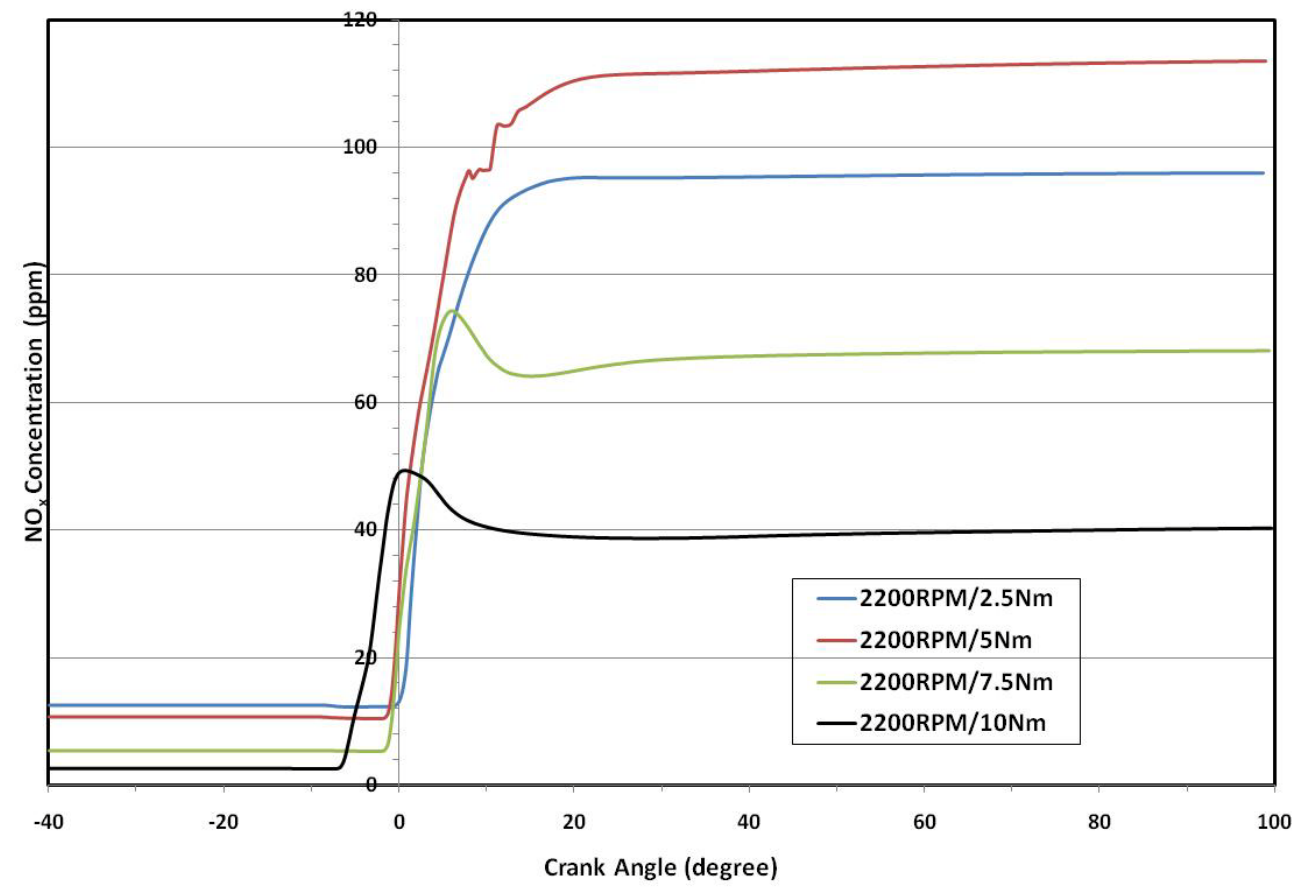

Figure 26. Simulation-predicted $\mathrm{NO}_{\mathrm{x}}$ concentration at engine speed of $2200 \mathrm{RPM}$ and engine loads of 2.5/5/7.5/10 Nm (B100 soybean biodiesel fuel) 


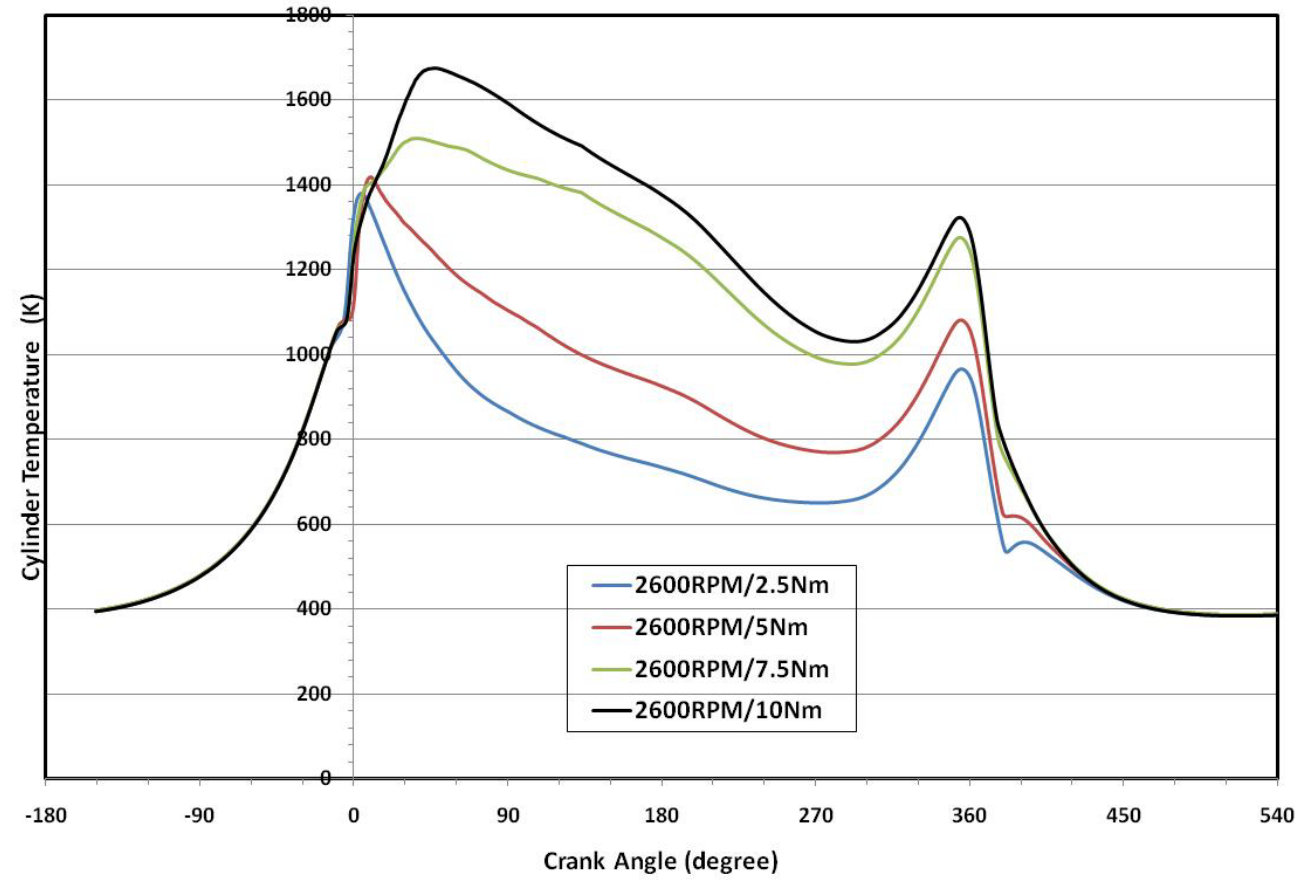

Figure 27. Simulation-predicted cylinder temperature at engine speed of 2600 RPM and engine loads of 2.5/5/7.5/10 Nm (B100 soybean biodiesel fuel)

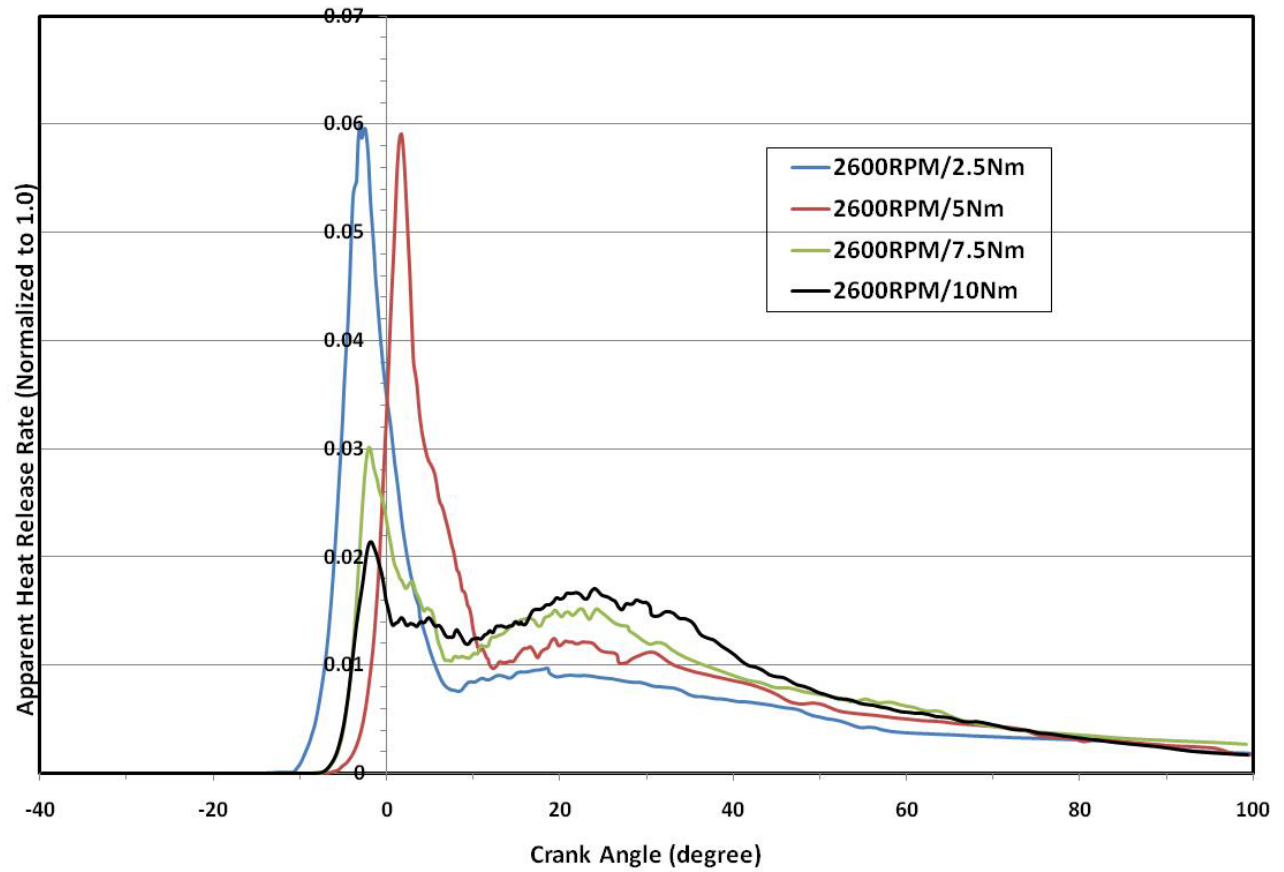

Figure 28. Simulation-predicted apparent heat release rate at engine speed of $2600 \mathrm{RPM}$ and engine loads of 2.5/5/7.5/10 Nm (B100 soybean biodiesel fuel) 


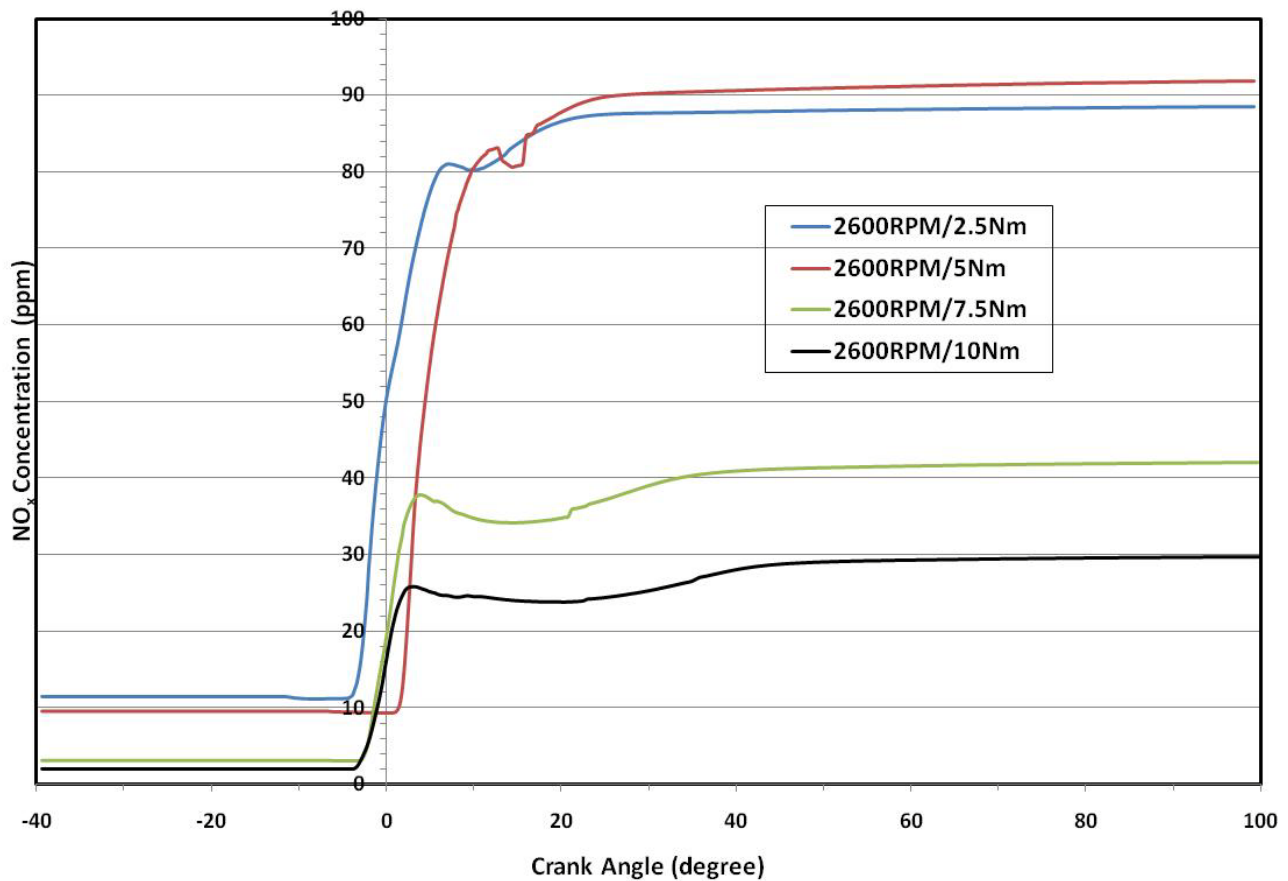

Figure 29. Simulation-predicted $\mathrm{NO}_{\mathrm{x}}$ concentration at engine speed of $2600 \mathrm{RPM}$ and engine loads of 2.5/5/7.5/10 Nm (B100 soybean biodiesel fuel)

For the B100 soybean biodiesel fuel, the test-measured and simulation-predicted combustion emissions concentrations of $\mathrm{NO}_{x}, \mathrm{HC}, \mathrm{CO}$, and $\mathrm{CO}_{2}$ are summarized and compared in tables 19 and 20. In these two tables, the A/F and Lambda stand for air-to-fuel ratio and excess air ratio, respectively; the emissions concentration values included in the parentheses are simulation-predicted results.

Table 19. Comparison between test-measured and simulation-predicted emissions for B100 soybean biodiesel fuel at engine speed of $2200 \mathrm{rpm}$

\begin{tabular}{|c|c|c|c|c|c|c|c|c|c|}
\hline $\begin{array}{l}\text { Engine speed } \\
\qquad \text { (rpm) }\end{array}$ & $\begin{array}{c}\text { Torque } \\
\text { (Nm) }\end{array}$ & $\begin{array}{l}\mathrm{NO}_{\mathrm{x}} \\
(\mathrm{ppm})\end{array}$ & $\begin{array}{c}\mathrm{CO} \\
(\mathrm{ppm})\end{array}$ & $\begin{array}{c}\mathrm{HC} \\
(\mathrm{ppm})\end{array}$ & $\begin{array}{c}\mathrm{CO}_{2} \\
(\mathrm{ppm})\end{array}$ & $A / F$ & $\begin{array}{c}\mathrm{O}_{2} \\
\text { (\%vol) }\end{array}$ & Lambda & $\begin{array}{l}\text { Injected fuel } \\
\text { mass per cycle } \\
\text { (mg) }\end{array}$ \\
\hline 2200 & 2.5 & $\begin{array}{c}75 \\
(96)\end{array}$ & $\begin{array}{c}400 \\
(1619)\end{array}$ & $\begin{array}{c}18 \\
(18)\end{array}$ & $\begin{array}{c}26400 \\
(39900)\end{array}$ & 93.7 & 17.5 & 6.52 & 8.027 \\
\hline 2200 & 5 & $\begin{array}{c}96 \\
(114)\end{array}$ & $\begin{array}{c}400 \\
(3924)\end{array}$ & $\begin{array}{c}19 \\
(23)\end{array}$ & $\begin{array}{c}36600 \\
(66432)\end{array}$ & 70.1 & 16.2 & 4.85 & 14.335 \\
\hline 2200 & 7.5 & $\begin{array}{l}113 \\
(68)\end{array}$ & $\begin{array}{c}700 \\
(841)\end{array}$ & $\begin{array}{l}19 \\
(2)\end{array}$ & $\begin{array}{c}49800 \\
(81652)\end{array}$ & 51.2 & 14.7 & 3.63 & 17.059 \\
\hline 2200 & 10 & $\begin{array}{l}128 \\
(41)\end{array}$ & $\begin{array}{c}2600 \\
(16797)\end{array}$ & $\begin{array}{c}21 \\
(22)\end{array}$ & $\begin{array}{c}67800 \\
(95287)\end{array}$ & 34.2 & 12.1 & 2.45 & 24.335 \\
\hline
\end{tabular}

(Note: emissions concentration values included in parentheses are simulation-predicted results.) 
Table 20. Comparison between test-measured and simulation-predicted emissions for B100 soybean biodiesel fuel at engine speed of $2600 \mathrm{rpm}$

\begin{tabular}{|c|c|c|c|c|c|c|c|c|c|}
\hline $\begin{array}{l}\text { Engine speed } \\
(\mathrm{rpm})\end{array}$ & $\begin{array}{l}\text { Torque } \\
(\mathrm{Nm})\end{array}$ & $\begin{array}{c}\mathrm{NO}_{\mathrm{x}} \\
(\mathrm{ppm})\end{array}$ & $\begin{array}{c}\text { CO } \\
\text { (ppm) }\end{array}$ & $\begin{array}{c}\mathrm{HC} \\
(\mathrm{ppm})\end{array}$ & $\begin{array}{c}\mathrm{CO}_{2} \\
(\mathrm{ppm})\end{array}$ & $A / F$ & $\begin{array}{c}\mathrm{O}_{2} \\
\text { (\%vol) }\end{array}$ & Lambda & $\begin{array}{l}\text { Injected fuel } \\
\text { mass per cycle } \\
\text { (mg) }\end{array}$ \\
\hline 2600 & 2.5 & $\begin{array}{c}71 \\
(89)\end{array}$ & $\begin{array}{c}1100 \\
(4915)\end{array}$ & $\begin{array}{c}9 \\
(70)\end{array}$ & $\begin{array}{c}35000 \\
(44966)\end{array}$ & 91.3 & 17.6 & 6.39 & 9.696 \\
\hline 2600 & 5 & $\begin{array}{c}84 \\
(92)\end{array}$ & $\begin{array}{c}1200 \\
(3786)\end{array}$ & $\begin{array}{c}10 \\
(48)\end{array}$ & $\begin{array}{c}40200 \\
(65583)\end{array}$ & 70.1 & 16.3 & 4.84 & 13.809 \\
\hline 2600 & 7.5 & $\begin{array}{c}99 \\
(42)\end{array}$ & $\begin{array}{c}1600 \\
(5320)\end{array}$ & $\begin{array}{l}24 \\
(7)\end{array}$ & $\begin{array}{c}60600 \\
(99746)\end{array}$ & 43.2 & 13.6 & 2.96 & 21.793 \\
\hline 2600 & 10 & $\begin{array}{l}122 \\
(30)\end{array}$ & $\begin{array}{c}3800 \\
(25523)\end{array}$ & $\begin{array}{c}25 \\
(40)\end{array}$ & $\begin{array}{c}82200 \\
(105444)\end{array}$ & 33 & 11.2 & 2.23 & 28.333 \\
\hline
\end{tabular}

(Note: emissions concentration values included in parentheses are simulation-predicted results.)

The GT-Power predictive combustion simulation direct-injection jet modeling is primarily developed to predict the $\mathrm{NO}_{\mathrm{x}}$ emissions using Extended Zeldovich mechanism, while the rest of emissions are calculated using equilibrium chemistry. Comparison between the simulation-predicted and test-measured emissions data shows relatively good agreement for the $\mathrm{NO}_{\mathrm{x}}$ emissions at lower engine loads. Although the trends in pollutant emissions with biodiesel content estimated from published engine dynamometer data (shown in figure 14) indicate the $\mathrm{B} 100$ biodiesel fuel reduces the $\mathrm{NO}_{\mathrm{x}}$ emissions by approximately $10 \%$, other combustion emission studies have also shown that the $\mathrm{NO}_{\mathrm{x}}$ emissions from biodiesel can increase or decrease depending on the engine family and testing procedures.

There are some relatively large differences between predicted and measured emissions in some of the tests. It is understandable that accurate emissions predictions are very difficult to accomplish due to limited combustion modeling capabilities resulted from insufficient scientific understanding of the tremendous complexities involved in the engine combustion. In addition, most of the required thermophysical property data had to be simulated as there was no reference data available. Potential inaccuracies associated with the biodiesel thermo-physical property estimations and fuel injector sac pressure measurements can also contribute to the discrepancies between the predicted and measured emissions. Given the limitations in accurate simulation approaches for the dynamics of combustion, the byproduct production during combustion, and the lack of validated reference data, the correlation with experiment is encouraging.

\section{7-CONCLUSIONS}

Various physical and thermodynamic properties of the biodiesel fuels in both liquid and vapor states are required by the engine combustion simulations. Many of these simulation-required fuel properties either do not exist or are not available in published literatures. The properties of the individual fatty esters, that comprise a biofuel, determine the overall fuel properties of the biofuel. In this research, fatty acid profiles 
of the soybean, cottonseed, and algae methylester biodiesels have been identified and used for fuel property calculations.

For the neat soybean biodiesel, engine emissions, which include $\mathrm{NO}_{\mathrm{x}}, \mathrm{HC}, \mathrm{CO}$ and $\mathrm{CO}_{2}$, measured at various engine speeds and loads were compared to those predicted by the combustion simulations. As for the cottonseed and algae biodiesels, which are not available from the market, engine emissions were predicted from combustion simulations and were compared to those of the conventional petroleum diesel to investigate the emission impacts of these biodiesel fuels. Reasonable success on the biodiesel combustion emissions predictions has been achieved in this study by using estimated fuel properties and measured fuel injector sac pressure profiles.

\section{ACKNOWLEDGMENT}

This work was supported by the United States Environmental Protection Agency under Grant \# XA833795-01-0. The authors wish to thank Prof. Wenqiao Yuan of Kansas State University for his permission and assistance of using the BDProp computer program to calculate certain physical and thermodynamic properties of the neat biodiesels that are of interest in this study.

\section{REFERENCES}

1. Srivastava, A. and Prasad, R., “Triglycerides-Based Diesel Fuels,” Renewable and Sustainable Energy Reviews, 2000.

2. Karabektas, M., Ergen, G., and Hosoz, M., "The Effects of Preheated Cottonseed Oil Methyl Ester on The Performance and Exhaust Emissions of A Diesel Engine,” Applied Thermal Engineering 28, 2008.

3. Sarmidi Amin, “Review on Biofuel Oil and Gas Production Processes from Microalgae,” Energy Conversion and Management 50, 2009.

4. Liu, H-P., Strank, S., Werst, M., Hebner, R., and Osara, J., “Combustion Emissions Modeling and Testing of Conventional Diesel Fuel,” ASME $20104^{\text {th }}$ International Conference on Energy Sustainability, Phoenix, Arizona, May 17-22, 2010.

5. Ruan, D. F., Cheng, W. L., and Lee, C. F., "Comparison of Performance and Combustion Characteristics of Diesel Fuel and Vegetable Oils in DI Diesel Engine,” 2008 SAE International Powertrains, Fuels and Lubricants Congress, Shanghai, China, June 23-25, 2008.

6. McCrady, J., Hansen, A., and Lee, C. F., “Modeling Biodiesel Combustion Using GT-Power,” 2007 ASABE Annual International Meeting, Minneapolis, Minnesota, June 17-20, 2007.

7. McCrady, J., Hansen, A., and Lee, C. F., "Combustion and Emissions Modeling of Biodiesel Using GT-Power,” 2008 ASABE Annual International Meeting, Providence, Rhode Island, June 29 - July 2, 2008.

8. Gamma Technologies, GT-Power User’s Manual (Version 6.2), September 2006.

9. Knothe, G., "Dependence of Biodiesel Fuel Properties on The Structure of Fatty Acid Alkyl Esters," Fuel Processing Technology 86, 2005.

10. Yuan, W., Computational Modeling of $\mathrm{NO}_{\mathrm{x}}$ Emissions from Biodiesel Combustion Based on Accurate Fuel Properties, Ph.D. Dissertation, University of Illinois at Urbana Champaign, 2005. 
11. Allen, C. A. W, Watts, K. C., Ackman, R. G., and Pegg, M. J., "Predicting the Viscosity of Biodiesel Fuels from Their Fatty Acid Ester Composition,” Fuel 78, 1999.

12. Graboski, M. S., McCormick, R. L., Alleman, T. L., and Herring, A. M., "The Effect of Biodiesel Composition on Engine Emissions from a DDC Series 60 Diesel Engine,” Final Report, Report 2 in a series of 6, NREL/SR-510-31461, February 2003.

13. Ma, F. and Hanna, M. A., "Biodiesel production: a review,” Bioresource Technology 70, 1999.

14. Filiz Karaosmanoglu, Melek Tuter, Emre Gollu, Sakine Yanmaz, and Esra Altintig, "Fuel Properties of Cottonseed Oil,” Energy Sources 21, 1999.

15. Tornabene, T. G., Holzer, G., Lien, S., and Burris, N., "Lipid Composition of the Nitrogen Starved Green Alga Neochloris Oleoabundans," Enzyme Microb. Technology, Vol. 5, November 1983.

16. Aresta, M., Dibenedetto, A., Carone, M., Colonna, T., and Fragale, C., "Production of Biodiesel from Macroalgae by Supercritical $\mathrm{CO}_{2}$ Extraction and Thermochemical Liquefaction," Environ Chem Lett 3, 2005.

17. Xu, H., Miao, X., and Wu, Q., "High Quality Biodiesel Production from a Microalga Chlorella Protothecoides by Heterotrophic Growth in Fermenters," Journal of Biotechnology 126, 2006.

18. Yuan, W., Hansen, A. C., and Zhang, Q., "Computational Modeling of NOx Emissions from Biodiesel Combustion,” Int. J. Vehicle Design, Vol. 45, Nos. 1/2, 2007.

19. Yuan, W., Hansen, A., and Zhang, Q., "The Specific Gravity of Biodiesel Fuels And Their Blends with Diesel Fuel," Agricultural Engineering International: the CIGR Journal of Scientific Research and Development. Manuscript EE 04 004. Vol. VI, September 2004.

20. Yuan, W., Hansen, A., Zhang, Q., and Tan, Z., "Temperature-Dependent Kinematic Viscosity of Selected Biodiesel Fuels and Blends with Diesel Fuel," JAOCS, Vol. 82, no. 3, 2005.

21. Reid, R. C., Prausnitz, J. M., and Poling, B. E., The Properties of Gases \& Liquids, $4^{\text {th }}$ Edition, McCraw-Hill, New York, NY, 1987.

22. Yaws, C. L., Chemical Properties Handbook, McGraw-Hill, New York, NY, 1999.

23. Canakci, M. and Sanli, H., "Biodiesel Production from Various Feedstocks and Their Effects on the Fuel Properties,” J. Ind. Microbiol Biotechnol 35, 2008.

24. United States Environmental Protection Agency. "A Comprehensive Analysis of Biodiesel Impacts On Exhaust Emissions”, Technical Report, EPA420-P-02001, 2002.

25. McCormick, R. L., Williams, A., Ireland, J., Brimhall, M., and Hayes, R. R., "Effects of Biodiesel Blends on Vehicle Emissions”, Milestone Report, NREL/MP-540-40554, October 2006. 